\title{
Discrimination of fluvial and eolian features on large ignimbrite sheets around La Pacana Caldera, Chile, using Landsat and SRTM-derived DEM
}

\author{
John E. Bailey $^{\mathrm{a}, *}$, Stephen Self ${ }^{\mathrm{b}}$, Luke K. Wooller ${ }^{\mathrm{b}}$, Peter J. Mouginis-Mark ${ }^{\mathrm{c}}$ \\ ${ }^{a}$ Alaska Volcano Observatory and Arctic Region Supercomputing Center, University of Alaska, Fairbanks, AK 99775, United States \\ b Volcano Dynamics Group, Department of Earth Sciences, Open University, Milton Keynes, MK7 6AA, England \\ ${ }^{\mathrm{c}}$ Hawaii Institute of Geophysics and Planetology, University of Hawaii at Manoa, Honolulu, HI 96822, USA
}

Received 27 December 2005; received in revised form 27 October 2006; accepted 28 October 2006

\begin{abstract}
Satellite images and ground-based observations were used to investigate the morphology and origin of valleys and ridges across large ignimbrite provinces around La Pacana Caldera, N. Chile. We studied 12 separate sites that included five different ignimbrite units that range in age from $\sim 5.6 \pm 0.5 \mathrm{Ma}$ to $1.35 \pm 0.15 \mathrm{Ma}$. Over 400 features from within these study sites were quantified. Study sites typically have dimensions of $25 \times 35 \mathrm{~km}$. Measurements were made using Landsat TM, ETM+, and SRTM-derived DEM and Shaded Relief images. Morphological measurements were made of the ridges and channels, including the direction of regional slope, length, orientation and gradient of each feature. A classification of the different ignimbrite erosion influences, resulting in varying landscape morphologies identified 4 landscape types; Fluvial, Eolian, Modified and Complex. We conclude that the most prevalent features are fluvial-derived channels but the most distinctive are linear, windderived ridges. The orientation of these ridges suggests that strong uni-directional winds from the northwest have been constant over a long period of time ( $>1 \mathrm{My})$.
\end{abstract}

(C) 2006 Elsevier Inc. All rights reserved.

Keywords: Ignimbrite; La Pacana; Erosion patterns; Landsat TM; SRTM

\section{Introduction}

One of the world's most extensive ignimbrite provinces lies within the Altiplano-Puna volcanic complex (APVC), between latitudes $21^{\circ}$ and $24^{\circ} \mathrm{S}$ in the Central Andes, Northern Chile (de Silva, 1989a; Guest, 1969; Pichler \& Zeil, 1972). Within this $50,000 \mathrm{~km}^{2}$ area (Fig. 1), a major period of volcanic activity occurred 3.5 to $6 \mathrm{Ma}$ ago during which several large ignimbrite deposits were emplaced, including the Puripicar (Guest, 1969) and the Atana Ignimbrites (Gardeweg \& Ramírez, 1987). The distribution, age, and origin of ignimbrites in the La Pacana area have been extensively described in various studies (Baker \& Francis, 1978; de Silva, 1987, 1989b; de Silva \&Francis, 1989; Gardeweg \& Ramírez, 1985, 1987; Guest, 1969; Lahsen, 1982; Lindsay, 1999; Lindsay et al., 2001a; Marinoviç \& Lahsen,

\footnotetext{
* Corresponding author. Tel.: +1 808474 6504; fax: +1 9074648603.

E-mail address: jbailey@gi.alaska.edu (J.E. Bailey).
}

1984; Ramírez \& Gardeweg, 1982; Rutland et al., 1965). However, few investigations have examined the geomorphology of the ignimbrite-dominated landscape, and in particular the origin of valley networks and ridges on the ignimbrite.

To investigate geomorphic features within the very widespread ignimbrite landscapes around La Pacana Caldera we used Landsat Thematic Mapper (TM) and Enhanced Thematic Mapper (ETM+) satellite images. Whilst the resolution of these images defines a 15 -meter limit to the size of features that can be seen, the sizes of the areas that can be studied are far greater than could practically be examined through only field studies. Similarly, the costs and limited availability of higher resolution satellite images (e.g., Ikonos and QuickBird) or aerial photographs are equally prohibitive for such a study. Observations using the Landsat data were aided by the use of Shuttle Radar Topography Mission (SRTM) data. The images show this region to contain a great number of linear and curvilinear surface features. A digital elevation model (DEM) and shaded relief image derived from 90-meter SRTM data, together with 


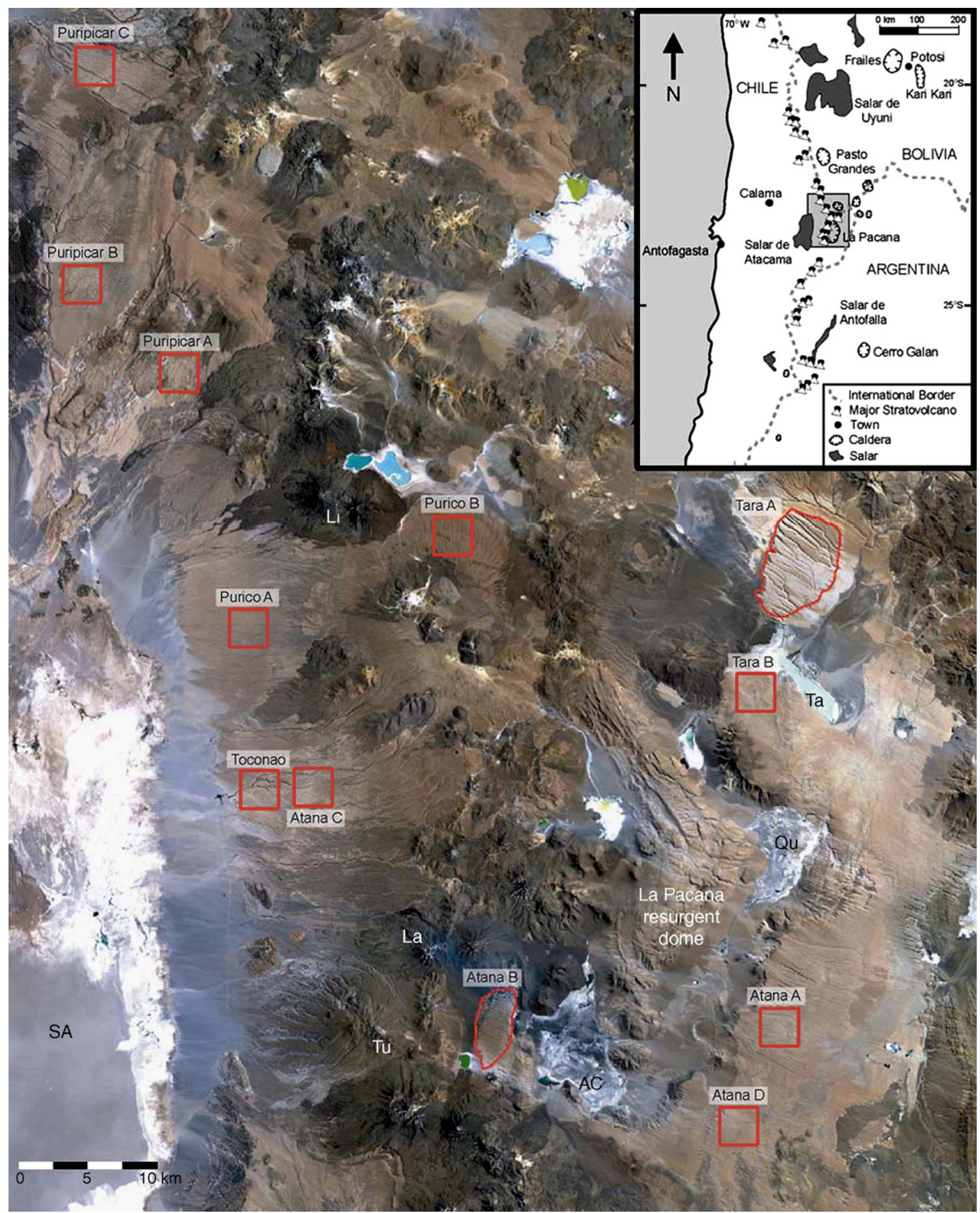

Fig. 1. Landsat TM (path 233 and 232, row 76) bands 3-2-1 RGB combination. Prominent features are marked: Salar de Aguas Calientes (AC), Volcan Lascar (La), Volcan Licancabur (Li), La Pacana resurgent dome (Pa), Salar de Quisquiro (Qu), Salar de Atacama (SA), Salar de Tara (Ta), and Cerro Tumisa (Tu). Study sites are outlined in red. Location map of study area (top right) adapted from Lindsay et al. (2001a,b).

field observations enabled us to identify features as channels or ridges. This study attempts to identify the nature and origin of the delineated features, and the geomorphic patterns they form.

The most distinctive patterns found result from a prolific number of northwest-southeast (NW-SE) trending linear features. A previous study of linear features within two of the ignimbrites in this area by Greene (1995) identified them as wind-eroded ridges called yardangs, which are elongate, positive topographic features that can be meters to kilometers long, and centimeters to 10's of meters wide. In contrast, Guest (1969) came to the conclusion that these ridges were of tectonic origin. Greene (1995) only considered the landscape to the NW of La Pacana Caldera, looking at yardangs within the Puripicar and Cerro Galan (Argentina) Ignimbrites. However, quantitative and qualitative analyses of the DEM and Landsat images show that NW-SE trending linear features are found in several 

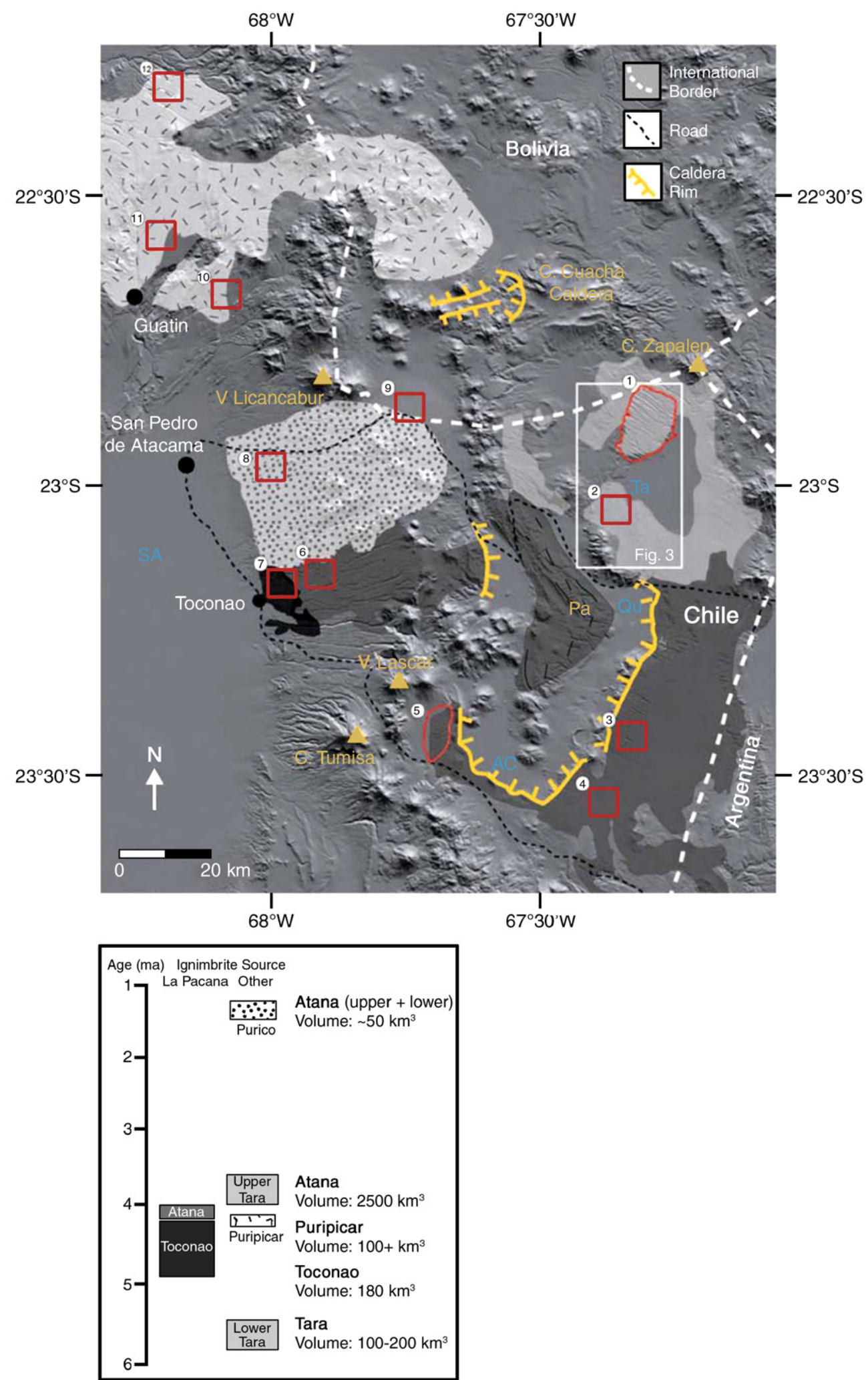

Fig. 2. Shaded-relief image of area around La Pacana Caldera, created from an SRTM-derived DEM, with illumination from the NE overlain by a simplified geologic map showing surface outcrops of the five ignimbrites of interest to this study (based on Francis et al., 1989; Lindsay et al., 2001a). Study sites are outlined in red: (1) Tara A, (2) Tara B, (3) Atana A, (4) Atana D, (5) Atana B, (6) Atana C, (7) Toconao, (8) Purico A, (9) Purico B, (10) Puripicar A, (11) Puripicar B, and (12) Puripicar C. Salars are marked by blue abbreviations the same is in Fig. 1. The white rectangle shows the location of Fig. 3. The key (bottom left) for identifying the ignimbrites shows best estimates of the ignimbrites' ages and volumes. 
ignimbrites in the region, aside from the Puripicar Ignimbrite. The SRTM-derived DEM shows these features to be comprised of both ridges and channels, and in some cases a complex interrelationship is shown between both. This suggests that in addition to eolian erosion, fluvial processes may have played an important role in shaping the landscape.

Although the flat to gently tilted, exposed ignimbrite sheets surrounding La Pacana Caldera are currently situated in the hyper-arid climate of the Atacama Desert, where the average annual rainfall is $<10 \mathrm{~mm}$ (Thompson et al., 2003), the role of free-flowing water should not be underestimated. Recent studies have shown that the climate in the Atacama Desert may have only been semi-arid since the time most of the ignimbrites were emplaced (Gaupp et al., 1999; Hartley \& Guillermo Chong, 2002). Other studies have also shown that wetter climatic periods have occurred over recent geologic history (Kull \& Grosjean, 1998; Latorre et al., 2003; Rech et al., 2002). The generally dry climate has allowed wind-driven erosion to become an important process, but it is suggested from the topography shown by the SRTM shaded relief map (Fig. 2) that fluvial erosion has been at least of equal importance in shaping the ignimbrite landscapes.

A primary goal of this study is to investigate the utility of the Landsat and SRTM data sets to facilitate the description and understanding of the origin of distinctive landforms identified in the La Pacana Caldera region. A total of 426 features has been identified in 12 different study sites; all but one of which measure $25-35 \mathrm{~km}^{2}$, with the other site $117 \mathrm{~km}^{2}$. Study sites are identified by the ignimbrite name and a letter in Figs. 1 and 2 . We attempt to provide a means of classifying different landscapes according to surface features visible in the satellite images. Classifications assume that straight ridges are typical of formation due to wind erosion, whilst more sinuous channels are representative of a fluvial environment. Based on these interpretations we also suggest what these landscape morphologies might imply about the erosion histories and possibly the climate of the region.

We begin with a brief overview of the regional ignimbrite geology. Next we describe the methods, and the results associated with delineating and characterizing geomorphic surface features based on remote sensing and field observations. This is followed by a consideration of the erosional processes that created the surface features and the patterns they form. We then attempt to categorize the landscape morphologies at each site, and account for the prevalent NW-SE alignment of many features, based on qualitative and quantitative analyses made using the Landsat images and SRTM data. We conclude with the implications that our observations have for the style of ignimbrite erosion in this arid climate and historical climate for the region.

\section{Geological setting}

The term ignimbrite is derived from the Latin words igni(fire) and imbri-(rain). It describes pyroclastic rocks formed by the widespread deposition and consolidation of pyroclastic flows (ashflows), violent eruptions of superheated gas and fragments of high-silica magma (Sparks et al., 1973). They can occur with various states of welding and consolidation due to alteration processes.

A large number of voluminous ignimbrites were emplaced within the APVC during the late Miocene to Pleistocene. One of these, the Atana Ignimbrite, has an estimated bulk volume of at
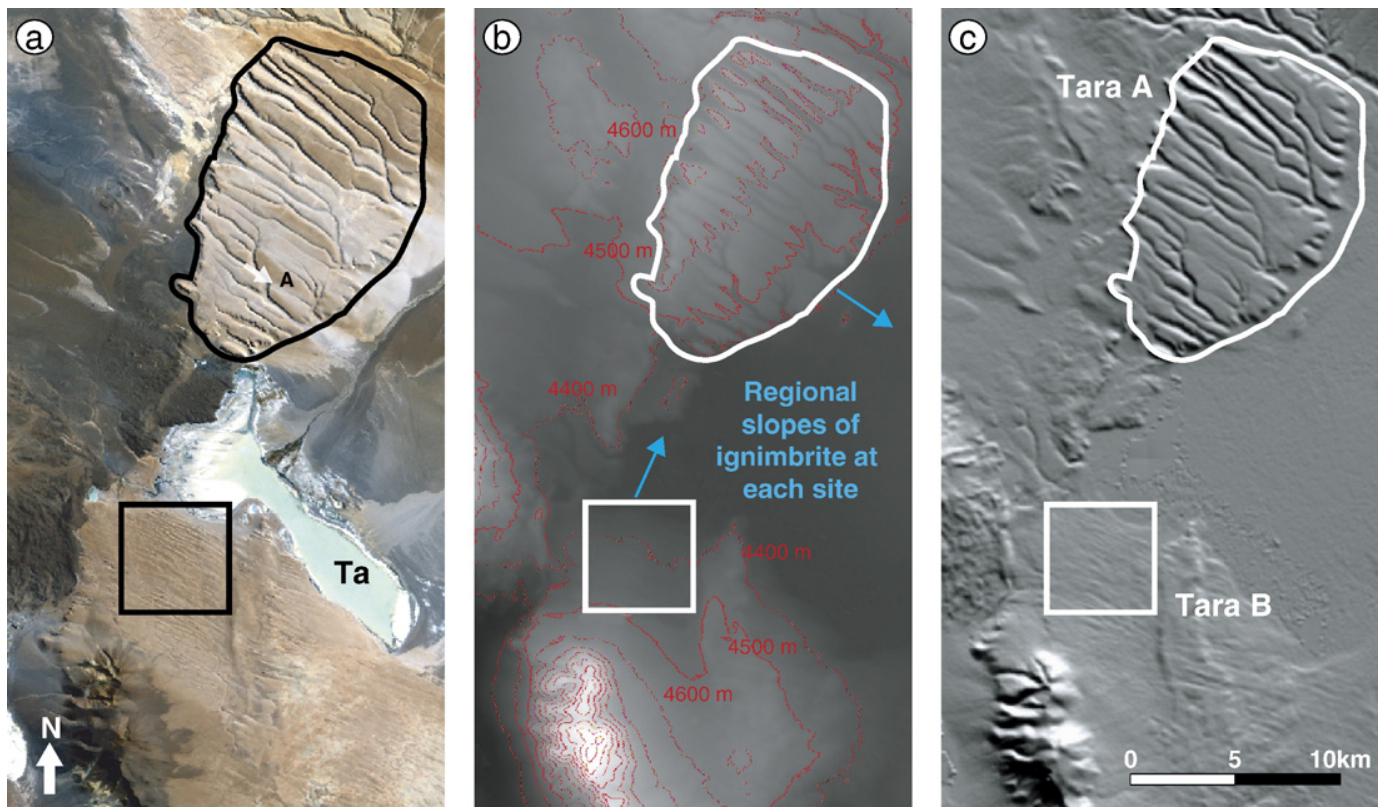

Fig. 3. Comparison of (a) Landsat TM (path 233 and 232, row 76) bands 3, 2, 1 RGB combination showing area near Salar de Tara (Ta). Location is marked in Fig. 2. Green arrow marks view shown in Fig. 9a of the path of an abandoned incipient channel (A). (b) SRTM-derived DEM showing same area as [a] and Tara Ignimbrite sites A and B. Red lines show contours. (c) Shaded Relief image derived from image [b], with illumination from the NE. Note the particularly prominent valley network at the Tara A site. 
least $2500 \mathrm{~km}^{3}$ (Lindsay et al., 2001a; Mason et al., 2004) making it the fourth largest ignimbrite deposit recognized in the world. The Atana Ignimbrite eruption led to the creation of La Pacana Caldera through a 'trap-door-like' collapse mechanism (Ramírez and Gardeweg, 1982). The $\sim 60 \times 25 \mathrm{~km}$ caldera was recognized by Gardeweg and Ramírez (1987) as one of the world's largest and best exposed resurgent calderas, with roughly elliptical geometry aligned along an $\mathrm{N}-\mathrm{S}$ trending major axis.

This study examines geomorphic features on the surface exposures of the five major, primarily dacitic, ignimbrite sheets that dominate the area around La Pacana Caldera (Fig. 2). The oldest is the Tara Ignimbrite, which is formed of two units. Lindsay et al. (2001a) dated the lower Tara Ignimbrite as $\sim 5.6 \pm$ $0.5 \mathrm{Ma}$ and the upper units as $\sim 3.8 \pm 0.2 \mathrm{Ma}$. The lower Tara has an average thickness of $\sim 10 \mathrm{~m}$ and the upper $<60 \mathrm{~m}$.

The dates of Tara Ignimbrite deposition bracket the estimated ages of three of the other ignimbrites studied. The Atana Ignimbrite is a huge-volume dacitic unit dated at $4.09 \pm$ $0.09 \mathrm{Ma}$. It has an average thickness of $40 \mathrm{~m}$ and is the larger member of the Atana formation (de Silva, 1989b), which includes the underlying rhyolitic Toconao Ignimbrite (Lindsay et al., 2001a). The Toconao Ignimbrite's exact age remains uncertain, as it is crystal-poor $(<10 \%)$, which makes dating difficult. Estimates place the age of the Toconao Ignimbrite between 4 and 5.8 Ma (Lindsay et al., 2001b), with an average thickness of $30 \mathrm{~m}$. Lindsay et al. (2001b) showed that La Pacana is the likely source of the Toconao Ignimbrite after identifying deposits to the east of the caldera, whereas before it had only been found to the west. The volume of the Atana Ignimbrite was previously overestimated by $\sim 200 \mathrm{~km}^{3}$, as it originally included the Tara sequence as part of its outflow sheet (Gardeweg \& Ramírez, 1987).

The $4.18 \pm 0.07$ Ma Puripicar Ignimbrite, lies to the northwest of La Pacana. It is stratigraphically equivalent to the Atana formation (de Silva, 1989b), but is thought to be a different eruptive unit derived from another source caldera, possibly located in southwestern Bolivia. The Puripicar is the thickest of the ignimbrites studied, typically $>70 \mathrm{~m}$. The youngest of the ignimbrites studied here is the $1.35 \pm 0.15 \mathrm{Ma}$ Purico Ignimbrite, which in some places directly overlies the Atana and Puripicar Ignimbrites. The Purico Ignimbrite has an upper and a lower unit, with the lower thicker (30 m average) than the upper (10-12 m). The lower Purico Ignimbrite was Guest's (1969) Cajon Ignimbrite. It was renamed the Purico Ignimbrite by Francis et al. (1989), after they defined the source as the Purico Complex.

The extent of surface exposures, volume estimates and relative ages of the five ignimbrites is shown in Fig. 2. For the purposes of considering surface geomorphology they can be considered homogeneous, sheet-like deposits.

Table 1

Summary of geometric measurements made for all 12 sites on the ignimbrite, using SRTM-derived DEM, Landsat TM and ETM+ data

\begin{tabular}{|c|c|c|c|c|c|c|c|c|c|c|c|c|}
\hline Ignimbrite site & Tara A & Tara B & Toconao & Puripicar A & Puripicar B & Puripicar C & Atana A & Atana B & Atana $\mathrm{C}$ & Atana D & Purico A & Purico B \\
\hline Total \# features & 42 & 25 & 28 & 50 & 71 & 32 & 17 & 40 & 54 & $\mathrm{n} / \mathrm{a}$ & 48 & 19 \\
\hline Study area $\left(\mathrm{km}^{2}\right)$ & 117 & 25 & 25 & 25 & 25 & 25 & 25 & 35 & 25 & 25 & 25 & 25 \\
\hline Regional slope $\left(^{\circ}\right)$ & 124 & 24 & 250 & 207 & 264 & 287 & 124 & 280 & 252 & 90 & 261 & 356 \\
\hline Classification & M & $\mathrm{E}$ & $\mathrm{C}$ & $\mathrm{E}$ & $\mathrm{C}$ & M & $\mathrm{F}$ & $\mathrm{M}$ & $\mathrm{C}$ & $\mathrm{E}$ & $\mathrm{F}$ & $\mathrm{F}$ \\
\hline \multicolumn{13}{|l|}{ Orientation $\left(^{\circ}\right)$} \\
\hline Max & 202 & 126 & 316 & 207 & 327 & 321 & 175 & 324 & 308 & 123 & 308 & 364 \\
\hline Min & 112 & 4 & 227 & 51 & 244 & 286 & 112 & 214 & 190 & 115 & 214 & 336 \\
\hline Mean & 138 & 110 & 286 & 154 & 297 & 297 & 130 & 285 & 287 & 109 & 267 & 351 \\
\hline$\sigma$ & 23 & 23 & 25 & 20 & 26 & 7 & 22 & 19 & 25 & 3 & 25 & 8 \\
\hline \multicolumn{13}{|l|}{$\Delta\left(^{\circ}\right)$} \\
\hline Max & 202 & 306 & 316 & 337 & 327 & 320 & 175 & 324 & 320 & $\mathrm{n} / \mathrm{a}$ & 308 & 358 \\
\hline Min & 112 & 4 & 227 & 139 & 136 & 111 & 112 & 214 & 111 & $\mathrm{n} / \mathrm{a}$ & 214 & 0 \\
\hline Mean & 16 & 88 & 39 & 54 & 56 & 19 & 15 & 14 & 40 & $\mathrm{n} / \mathrm{a}$ & 20 & 7 \\
\hline$\sigma$ & 21 & 15 & 20 & 24 & 47 & 37 & 16 & 15 & 17 & $\mathrm{n} / \mathrm{a}$ & 16 & 6 \\
\hline \multicolumn{13}{|l|}{$G_{\text {avg }}(\mathrm{m} / \mathrm{m})$} \\
\hline Max & 0.072 & 0.032 & 0.158 & 0.139 & 0.200 & 0.089 & 0.059 & 0.248 & 0.105 & $\mathrm{n} / \mathrm{a}$ & 0.341 & 0.052 \\
\hline Min & 0.013 & 0.000 & 0.320 & 0.013 & 0.025 & 0.036 & 0.000 & 0.023 & 0.002 & $\mathrm{n} / \mathrm{a}$ & 0.057 & 0.080 \\
\hline Mean & 0.037 & 0.008 & 0.078 & 0.073 & 0.079 & 0.046 & 0.038 & 0.078 & 0.065 & $\mathrm{n} / \mathrm{a}$ & 0.104 & 0.047 \\
\hline$\sigma$ & 0.013 & 0.008 & 0.029 & 0.026 & 0.027 & 0.010 & 0.017 & 0.033 & 0.020 & $\mathrm{n} / \mathrm{a}$ & 0.044 & 0.004 \\
\hline \multicolumn{13}{|l|}{$L_{\mathrm{f}}(\mathrm{m})$} \\
\hline Max & 8160 & 4020 & 5340 & 5280 & 5460 & 6060 & 10650 & 3360 & 8280 & $\mathrm{n} / \mathrm{a}$ & 5460 & 8310 \\
\hline Min & 240 & 480 & 120 & 180 & 240 & 180 & 270 & 210 & 300 & $\mathrm{n} / \mathrm{a}$ & 240 & ] 750 \\
\hline Mean & 3035 & 2088 & 1787 & 1436 & 1555 & 2723 & 5935 & 1685 & 1842 & $\mathrm{n} / \mathrm{a}$ & 1766 & 4475 \\
\hline$\sigma$ & 2165 & 1256 & 1423 & 1150 & 1091 & 1724 & 4132 & 941 & 1738 & $\mathrm{n} / \mathrm{a}$ & 1646 & 2503 \\
\hline \multicolumn{13}{|l|}{$S(\mathrm{~m} / \mathrm{m})$} \\
\hline Max & 1.169 & 1.072 & 1.189 & 1.124 & 1.400 & 1.200 & 1.125 & 1.111 & 1.353 & $\mathrm{n} / \mathrm{a}$ & 1.133 & 1.074 \\
\hline Min & 1.000 & 1.000 & 1.000 & 1.000 & 1.000 & 1.000 & 1.000 & 1.000 & 1.000 & $\mathrm{n} / \mathrm{a}$ & 1.000 & 1.000 \\
\hline Mean & 1.043 & 1.016 & 1.057 & 1.021 & 1.055 & 1.035 & 1.049 & 1.023 & 1.072 & $\mathrm{n} / \mathrm{a}$ & 1.029 & 1.030 \\
\hline$\sigma$ & 0.036 & 0.019 & 0.054 & 0.030 & 0.081 & 0.038 & 0.040 & 0.030 & 0.075 & $\mathrm{n} / \mathrm{a}$ & 0.034 & 0.020 \\
\hline
\end{tabular}

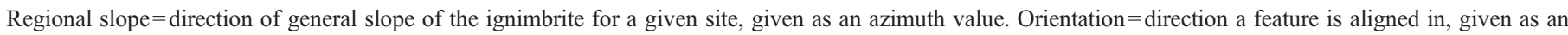

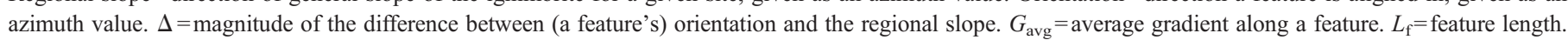
$S=$ sinuosity. 


\section{Remote sensing datasets and defined features}

This study used SRTM and Landsat data (Figs. 1 and 2). Landsat TM and ETM+ data were primarily used for mapping because of their higher spatial resolution $(30 \mathrm{~m} /$ pixel multispectral data and $15 \mathrm{~m} /$ pixel for ETM+ panchromatic data). Two images from adjacent paths were required to give coverage over the whole area of interest. The TM images used were acquired on 27th October 1989 (Path 233, Row 76) and 22nd April 1990 (Path 232, Row 76). The ETM+ images used were acquired on 5th February 2000 (Path 232, Row 76) and 12th October 2001 (Path 233, Row 76). The time discrepancy between the images is not a concern for the area studied, as the current arid climate of the Atacama Desert means that the landscape has changed very little between 1989 and 2001. Most of the features studied have likely taken 100,000 years to millions of years to develop.

An SRTM-derived digital elevation model (DEM) was used to estimate the slope of the topography in the areas studied and aspect of each of the valleys and ridges on the ignimbrites. These topographic data were collected during a mission flown by the Space Shuttle Endeavor between 11th and 22nd February 2000, and have a $90 \mathrm{~m}$ spatial resolution and a vertical resolution of 12 to $16 \mathrm{~m}$ (Farr and Kobrck, 2000; Rabus et al., 2003). All the datasets were co-registered using ENVI image processing package, with the Landsat TM image as the base image.

Morphological measurements were made for 12 sites around La Pacana Caldera. Site selection was based on visual determina- tion of areas that contained the NW-SE trending linear features of interest and other representative landscape morphologies of an area. Areas were defined according to the ignimbrite exposed at the surface. Channels and ridges were identified from the Landsat and SRTM-derived data as linear or curvilinear features (Fig. 3). The DEM was used to classify a feature as a ridge or channel, as well as the down-slope direction of the ignimbrite surface at a given study slope, defined as regional slope (Table 1). However, the DEM's 12-16 m vertical resolution (Farr and Kobrck, 2000) is not good enough to allow meaningful height and depth measurements of individual features.

Features were further categorized based on alignment relative to regional slope. Features were defined as either aligning the slope (along-slope) or transverse to it (cross-slope). A feature was defined as aligned along-slope if its orientation was equal to the regional slope orientation $\pm 20^{\circ}$, or cross-slope if the difference is $>20^{\circ}$. Digital feature maps were created and used to define the orientations of the channels and ridges (Fig. 4).

Channels were defined as uni-directional, and orientation given as their azimuth in either an easterly (between $0^{\circ}$ and $179^{\circ}$ ) or westerly $\left(180^{\circ}\right.$ to $\left.360^{\circ}\right)$ direction, depending on whether the regional slope is orientated $\mathrm{E}$ or $\mathrm{W}$. Ridges were taken as bidirectional, as initially no assumptions were made about the dominant wind-direction that is assumed to have formed them. The ridges' orientation was recorded as two azimuth values (Table 1).

The panchromatic ( $15 \mathrm{~m} /$ pixel) Landsat images were used to measure the length of each delineated feature. Both the full
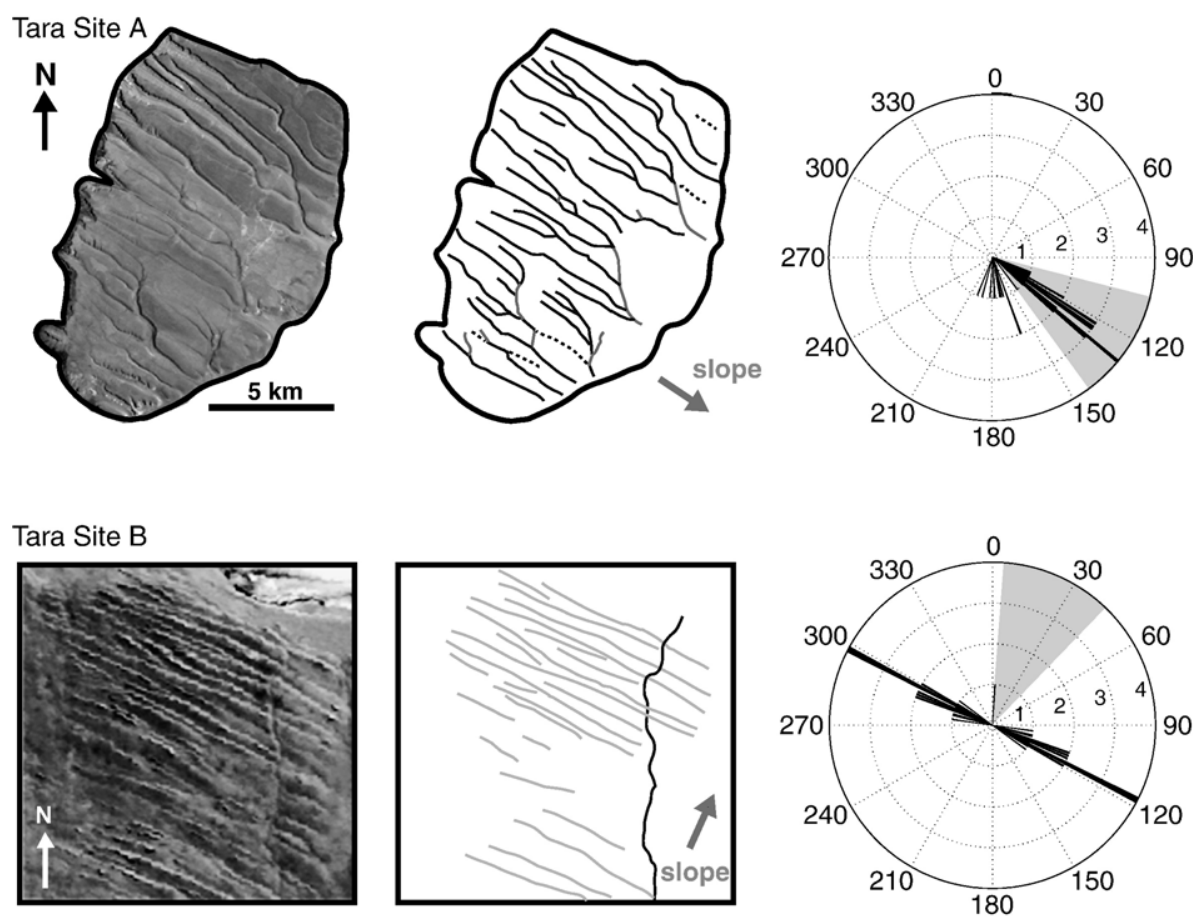

Fig. 4. Landsat ETM+ panchromatic $(0.5-0.9 \mu \mathrm{m})$ images for Tara study sites (left). Sun illumination is from the NE. Site B is an area $5 \times 5 \mathrm{~km}$ in size. Delineated feature maps are shown for the two sites (center). Line width is not representative of feature width. Dark lines are channels aligned along-slope. Lighter lines are channels (site A) and ridges (site B) aligned cross-slope. Regional slope is indicated by the grey arrows. The rose diagrams (right) illustrate the features' orientations as values of azimuth, plotted in increments of $1^{\circ}$. The integers indicate the count of features in the same direction. The shaded gray wedge indicates orientations defined as along-slope. 
length, accounting for curves in the feature $\left(L_{\mathrm{f}}\right)$, and the straightline distance from the start to the end of the feature $\left(L_{\mathrm{s}}\right)$, were measured. This enabled calculation of sinuosity, a dimensionless value that provides a measure of the degree to which a curvilinear feature bends about the shortest route between two points.

$S=L_{\mathrm{f}} / L_{\mathrm{s}}$

The average gradient $\left(G_{\text {avg }}\right)$ along a feature could also be calculated using the feature length, and measurements from the DEM of the elevation at the start and end of a feature:

$G_{\text {avg }}=($ Uphill elevation-Downhill elevation $) / L_{\mathrm{f}}$

The mean of all measurements of orientation, length, sinuosity and average gradient of delineated features were for calculated for each area, and assumed to be representative of that landscape (Table 1).

Measurement of widths was difficult as these values can vary greatly along a feature (especially for channels) and are close to the spatial resolution of the datasets. Therefore, collected width data were not useful in discriminating between different features. The widths of some features are comparable in size to the resolution limits of the image data, such that they could be identified in the Landsat images, but not with any certainty in the DEM. It was therefore not always possible to define them as a ridge or channel. This was particularly apparent for the NW-SE aligned linear features at Puripicar site A and B.

\section{Eolian and fluvial erosion, and regional climate}

In order to understand the origins of the features seen in the satellite images, and to categorize the landscapes they define, the two dominant erosion processes occurring, eolian and fluvial erosion, must be considered. The occurrence of eolian erosion is not surprising given the barren, non-vegetated landscape. Even the more consolidated deposits will eventually be worn down if left exposed to wind for a long period of time, i.e., the several million years that have passed since deposition of most of the ignimbrites. Greene's (1995) study of the yardangs in the Puripicar estimate formation began at least 0.1 to $2 \mathrm{Ma}$ ago. A lava flow that overlies one area of yardangs was dated at $0.8 \mathrm{Ma}$ (Greene, 1995), which places a lower limit on the age of those features. Using Embabi's (1999) conceptual model for the stages of eolian erosion of yardangs (Fig. 5a,b), Brookes (2001) estimated that the landscape in the Dakhla Desert goes through life cycles lasting at least 1.0 Ma.
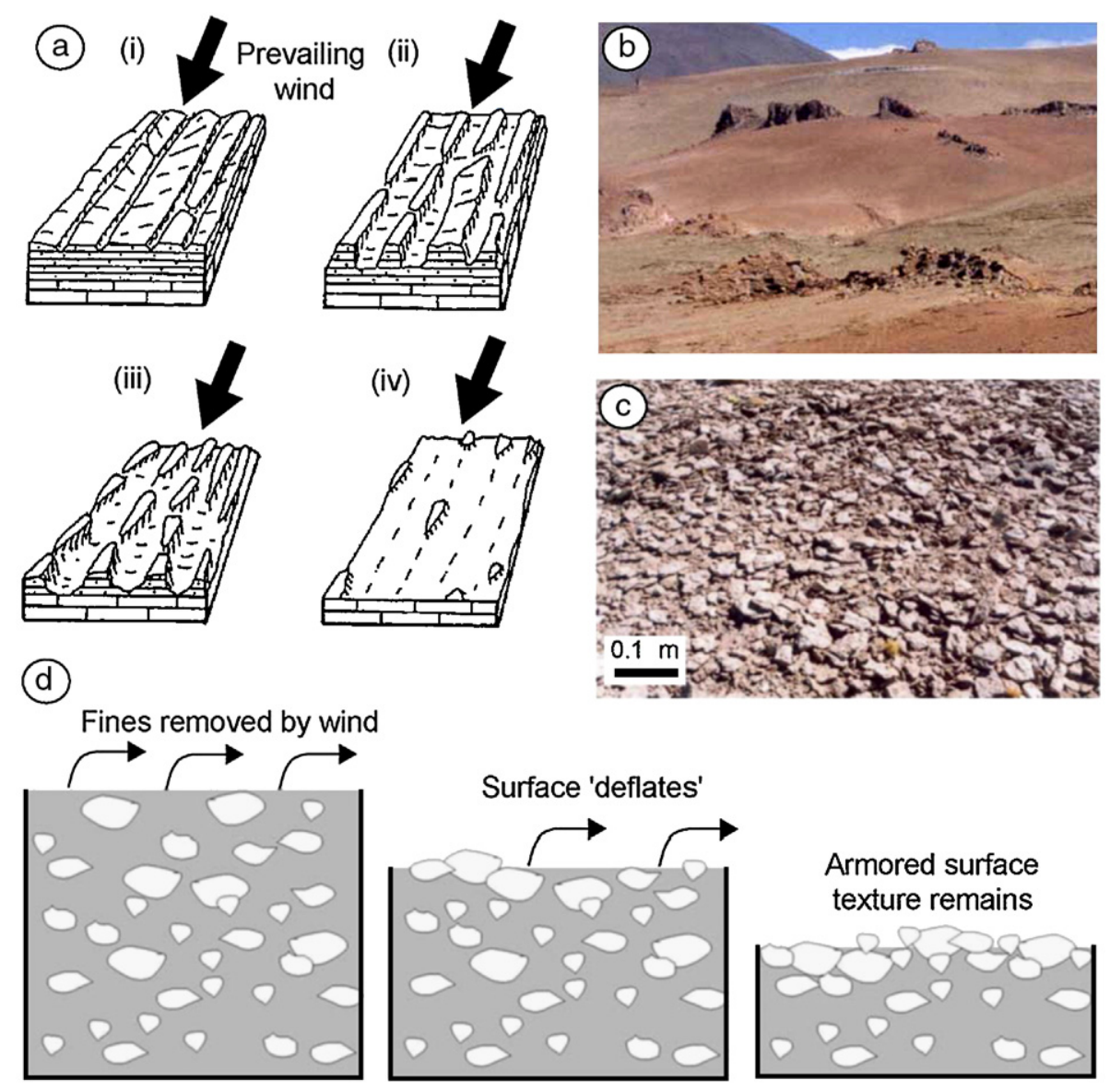

Fig. 5. Characteristics of eolian erosion on desert-type landscapes. (a) Embabi's (1999) conceptual model for the stages of eolian erosion of yardangs. (b) Example of erosion stage (iii) to (iv) at Tara B. (c) Desert pavement surface at Tara A. (d) The process of deflation due to removal of fine material by the wind. 
(a) Along-slope

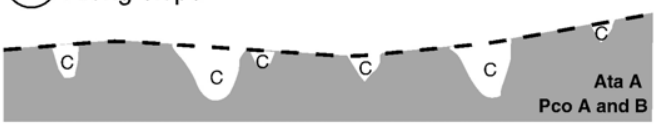

(b) Along-slope

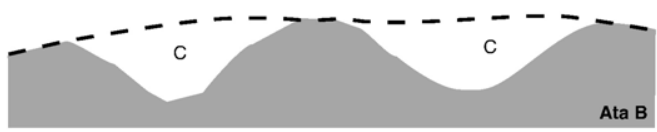

(C) Along-slope

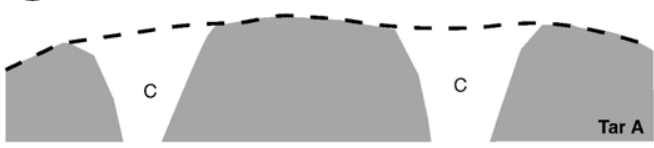

(d) Along-slope

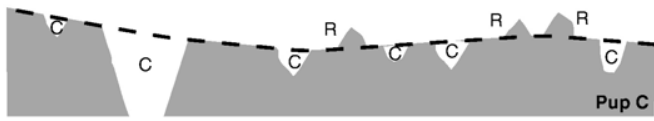

(e) Cross-slope

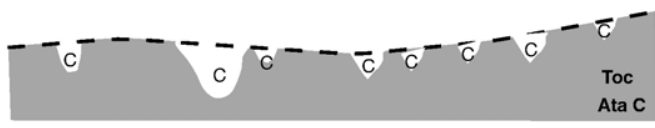

(f) Cross-slope

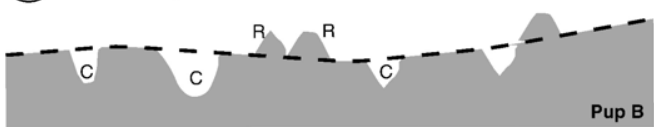

(g) Cross-slope

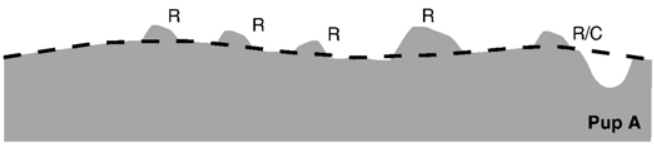

(h) Cross-slope

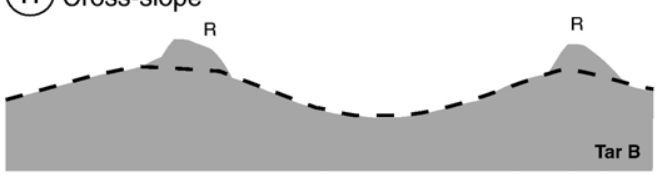

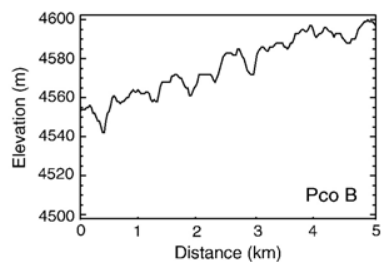
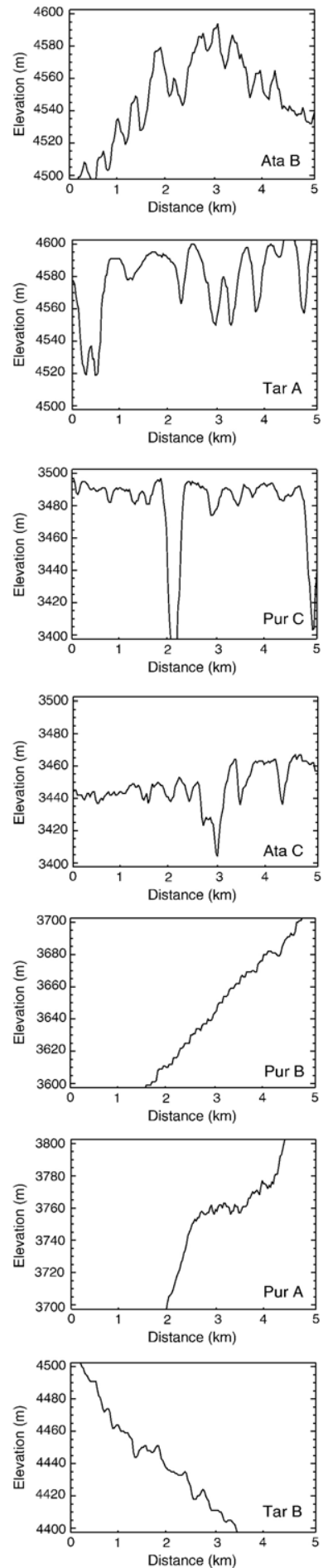

Fig. 6. Cross-sectional views showing various topographic features at the sites studied in this investigation. Eight typical arrangements of ridges (R), channels (C) and ridge/channel combinations (R/C) were identified (left), based on qualitative analysis of the DEM. Examples of topographic profiles taken from the DEM are shown (right). The profiles were made across the study sites, perpendicular to the primary orientation of features. Sites where each morphology prevails are indicated in bottom right corners; abbreviations used for Tara (Tar), Toconao (Toc), Puripicar (Pup), Atana (Ata) and Purico (Pco). 
If the wind maintains a constant direction it can have a distinctive effect on the landscape, sculpting parallel linear features and lines of pits (Whitney, 1978). Constant winds can also "lower" surfaces by the removing of unconsolidated, finer material. This process is called deflation and creates the armored surface texture known as desert pavement (Fig. 5c,d), which was observed most notably on the Tara Ignimbrite.
The relative amount of rainfall over the study areas will have also influenced the styles of erosion that dominated and the type of features that formed. The occurrence of fluvial activity might be more surprising, given that the Atacama Desert is one of the world's most hyper-arid regions. Studies have suggested that desertification in the Atacama region commenced during in the middle Miocene $(\sim 14 \mathrm{Ma})$ during global climate desiccation
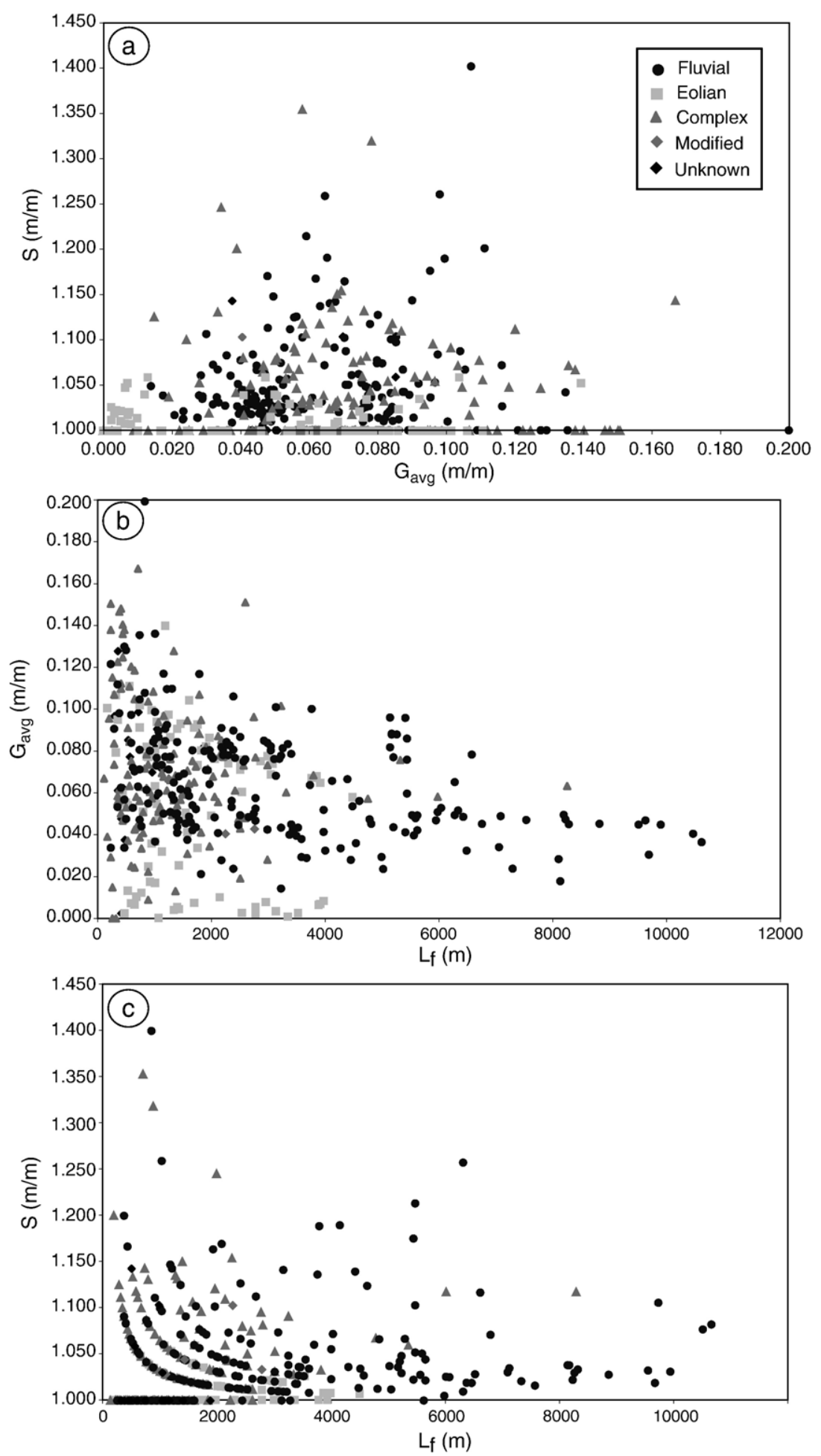

Fig. 7. Comparisons of geomorphic characteristics. (a) Sinuosity (S) vs. average gradient along feature ( $\left.G_{\text {avg }}\right)$. (b) $G_{\text {avg }}$ vs. feature length $\left(L_{\mathrm{f}}\right)$. (c) $S$ vs. $L_{\mathrm{f}}$. 
associated with development of the Antarctic ice cap (Alpers \& Brimhall, 1988; Clark et al., 1967). This is prior to the emplacement of the ignimbrites studied. However, more recent studies have suggested that the hyper-aridity might not have been established for as long or as permanently as previously suggested.

The current hyper-arid climate in the Atacama Desert is due to a combination of (1) subtropical atmospheric subsidence; (2) the upwelling, north-flowing, cold Humboldt Current, which prevents precipitation in the coastal regions; and (3) the rainshadow effect of the Andean Cordillera (Hartley \& Guillermo Chong, 2002). These conditions were inferred to have commenced in the middle Miocene on the basis of a combination of the age of supergene enrichment profiles developed above porphyry copper deposits (Alpers \& Brimhall, 1988; Sillitoe \& McKee, 1996) and geomorphologic studies (Clark et al., 1990; Galli-Oliver, 1967; Mortimer \& Saric, 1975; Mortimer et al., 1974). However, these studies do not agree on the timing of the onset of hyper-aridity. They suggest a range of timings from 9 to $14 \mathrm{Ma}$, which is also not supported by stratigraphic and sedimentologic evidence from the center of the Atacama Desert (Gaupp et al., 1999; Hartley \& Guillermo Chong, 2002). These later studies argue that a semi-arid climate persisted from 8 to 3 Ma (Hartley \& Guillermo Chong, 2002), punctuated by a phase of increased aridity at ca. $6 \mathrm{Ma}$ (Gaupp et al., 1999). As such, hyper-aridity did not commence until the late Pliocene, and was the result of global climate change (Hartley \& Guillermo Chong, 2002). Even beyond $3 \mathrm{Ma}$, studies of vegetation histories (Latorre et al., 2003) and paleohydrology (Rech et al., 2002) have shown that wetter climate phases have occurred. Reconstructions of albedo have also indicated variations in humidity over the last $20 \mathrm{ka}$ that were related to climate changes and Milankovitch cycles (Kull \& Grosjean, 1998). When rainfall does occur in the Atacama Desert it is generally very intense and can cause widespread flash flooding (Houston, 2001, 2002), that may excavate many small rills and gullies on the ignimbrites.

The fact that some surface features are aligned with the slope, and others transverse to it, suggests that there are different relative influences of fluvial and eolian erosion. We would assume that generally the topographic ridges are a result of winderosion in a dominant direction and channels result from fluvial activity. Initially fluvial channels are typically consequent, forming in the direction of runoff as determined by regional slope. However, over time, structural influences may allow channels to become subsequent. If fluvial activity only occurs very infrequently it could also be possible for wind erosion to occur first and then be modified by erosion due to flowing water. This can lead to the formation of channels that have sudden
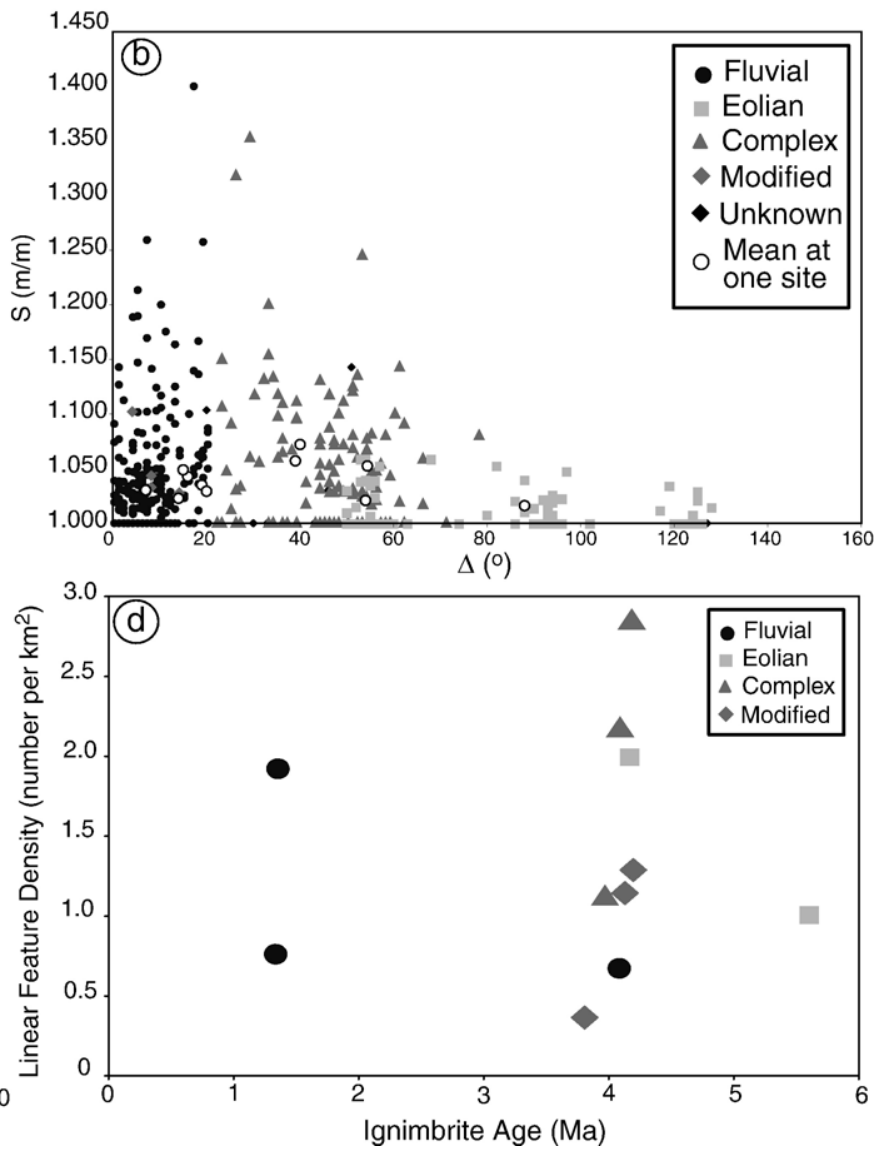

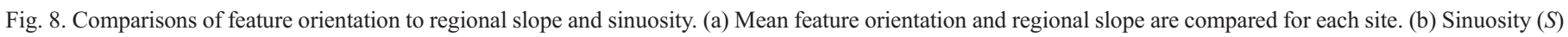

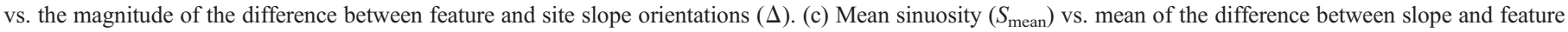

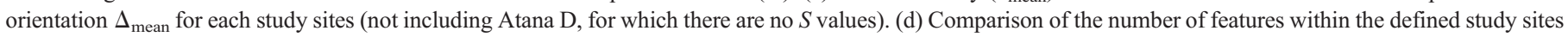
to the age of the surface ignimbrite. 
jumps in their courses, as they follow existing landforms (e.g., at Toconao, Puripicar B, Atana C sites). It is also possible for channels to be modified by wind as fluvial erosion exposes less consolidated ignimbrite below upper altered or partially welded zones. This is particularly true if the dominant wind direction is aligned along or close to the direction of slope (i.e. the initial consequent direction in which channels form).

\section{Analysis of landscape features}

Categorization of surface features as either ridges/channels, or as aligned along/cross-slope is not definitive in terms of defining whether they were formed by eolian, fluvial erosion or both. However, used in combination we can define four defini- tions of feature types that are suggestive of their origins; Fluvial (F), Modified (M), Complex (C) and Eolian (E). Fluvial features are channels along-slope, Eolian features are ridges cross-slope, modified are ridges along-slope and complex features are channels cross-slope. These definitions provide qualitative descriptions of the features creating different landscape morphologies. Fig. 6 highlights these morphologies using examples of topographic profiles (right) and schematic cross-sections (left). However, to improve the classification of sites, it was necessary to compare quantitative geomorphic characteristics of the surface features (Table 1).

Without obtaining ground-truth information for all 426 of the surface features identified and measured in this study, it is not possible to be certain about the exact characteristics of each
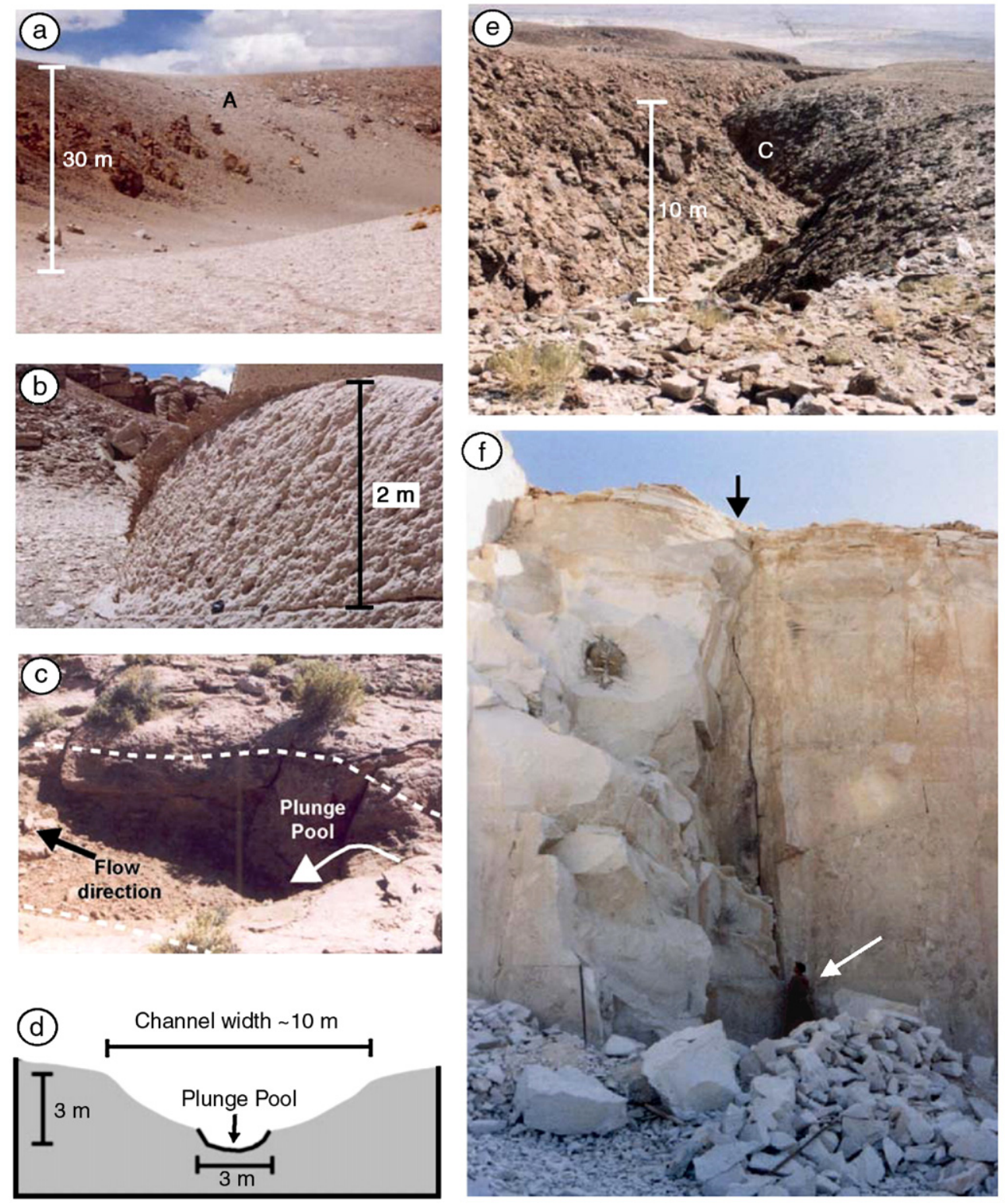

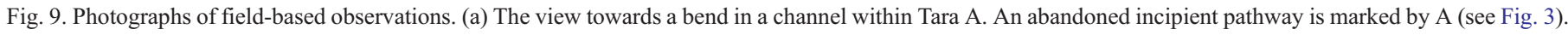

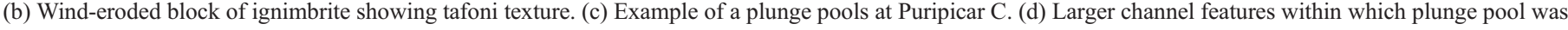

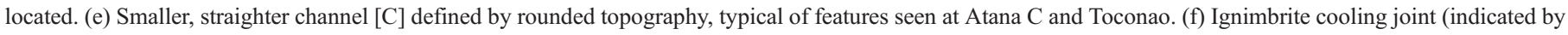
black arrow) at Toconao quarry. Person at base of scarp in partial shadow (white arrow) provides scale. 
feature. Mapping out individual feature dimensions was not the goal of this study, nor was defining every surface feature in a study area, as many are smaller than the spatial resolution of the images. We attempted to look for the typical characteristics of a study site that can be measured using the DEM and Landsat images, and to see if differences identify different landscapes. Thus, mean values of measurement orientations, average gradient, length and sinuosity (Table 1).

A comparison of average gradient and sinuosity shows that features categorized as eolian are not found for $S>1.06$ (Fig. 7a), but there appears to be no obvious relationship between the two characteristics. Similarly, length vs. average gradient shows eolian ridges reach a maximum of $\sim 4 \mathrm{~km}$, whilst fluvial channels can be 3 times that (Fig. 7b), but there is no apparent relationship between the two characteristics. A comparison of sinuosity vs. length is more informative (Fig. 7c), suggesting that fluvial channels have a wide range of sinuosity and lengths; eolian ridges have zero to low sinuosity, and limited length; and complex features are generally shorter (like ridges) but have a range of sinuosity (like channels).

Fig. 8a shows values of the mean orientation for each of the 12 sites studied here (with errors of $\pm 1 \sigma$ ), and compares them to orientation of the regional slope. For many of the sites these values are very similar, but for others there are moderate to large differences. The conclusion drawn from this is that the forces forming surface features are partly but not wholly dependent on the regional slope. The approximately NW-SE trends of many features are also highlighted by the fact that many of the values of mean orientation are close to $315^{\circ}(\mathrm{NW})$ or $135^{\circ}(\mathrm{SE})$.

The relationship between orientation and regional slope was examined by calculating the (positive) difference between the two values $(\Delta)$. This was then compared to $S$ for each feature, and distinctive distributions were observed (Fig. 8b). The separation between fluvial and complex or eolian features was expected, as the relationship to slope is inherent in how the features were categorized. The separation between complex (cross-slope channels) and eolian (cross-slope ridges) highlights the quantitative distinctions between different landscapes. Fig. 8c plots $\Delta_{\text {mean }}$ vs. $S_{\text {mean }}$ and defines areas of fluvial-dominated, eoliandominate and complex morphologies based on the trends shown by Fig. $8 b$.

\section{Categorization of landscape morphologies}

Atana A and Purico A and B all contain features that are predominantly curvilinear channels forming bifurcated
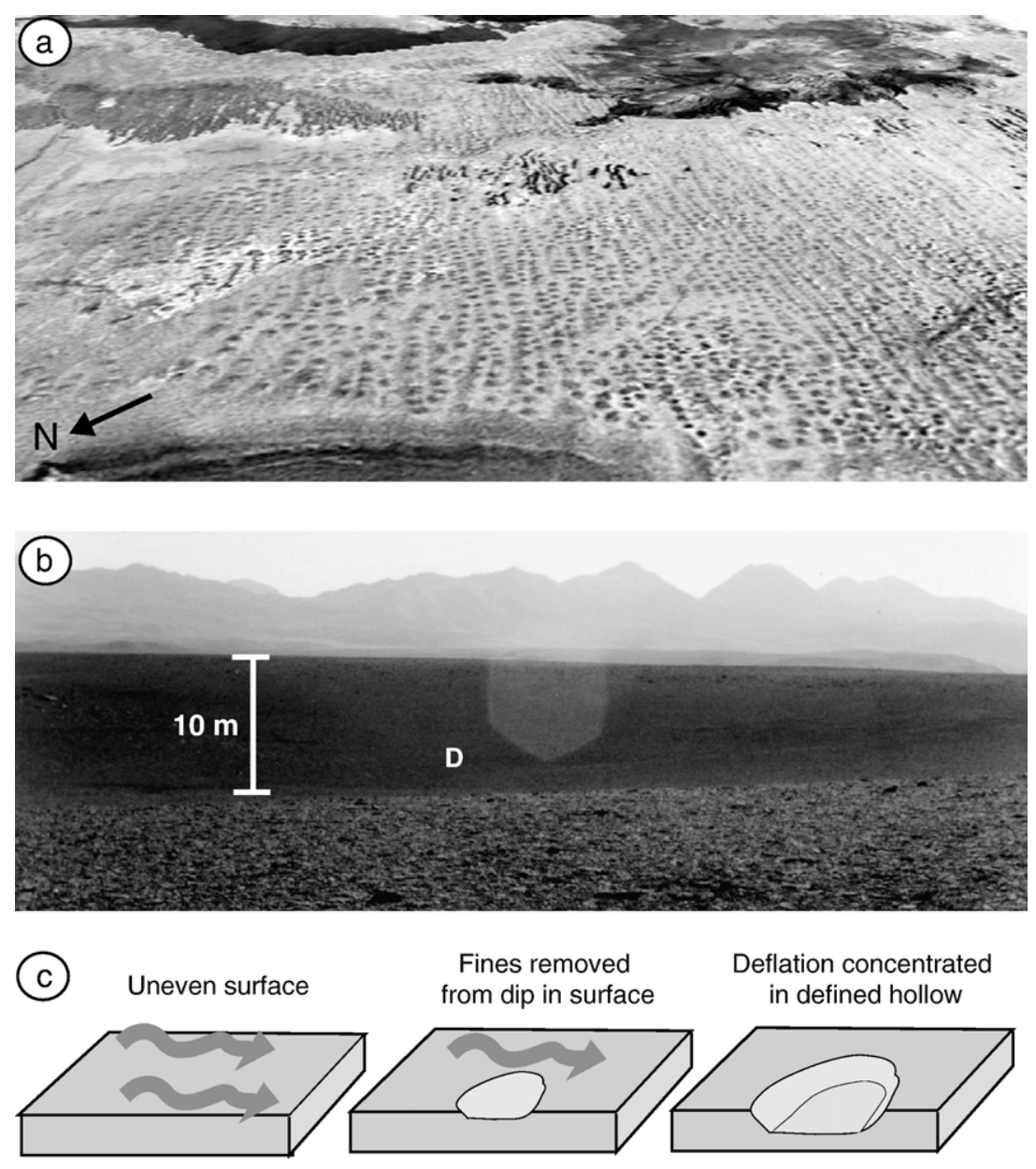

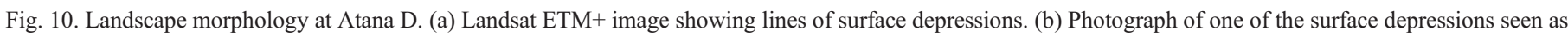

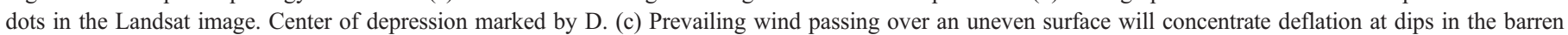
surface. This leads to the formation of deflation pits, also known as blowouts. 
drainage patterns that are aligned with slope (Howard, 1967). These exhibit low $\Delta$ values and a range of $S$ values, predominantly between 1 and 1.25 . The mean values plotted in Fig. $8 \mathrm{c}$ are similar for all three sites. The DEM shows that a similar type of topography exists at all three sites (Fig. 6a), and suggests these landscapes are primarily fluvial channels. At Atana A, the mean feature orientation and slope are aligned in the same direction, following an NW-SE trend. This is also seen for the features at Tara B, Atana B and Puripicar C, which plot at similar values to the fluvial features on Fig. 8c. Wind does not appear to have played a significant role in shaping the landscape at Atana A, but at the other three sites it appears that it has.

The deep, curvilinear channels carved into the ignimbrite at Tara A seem to be typical of fluvial erosion (Fig. 9a), but evidence shows significant modification due to wind. Crosscutting of

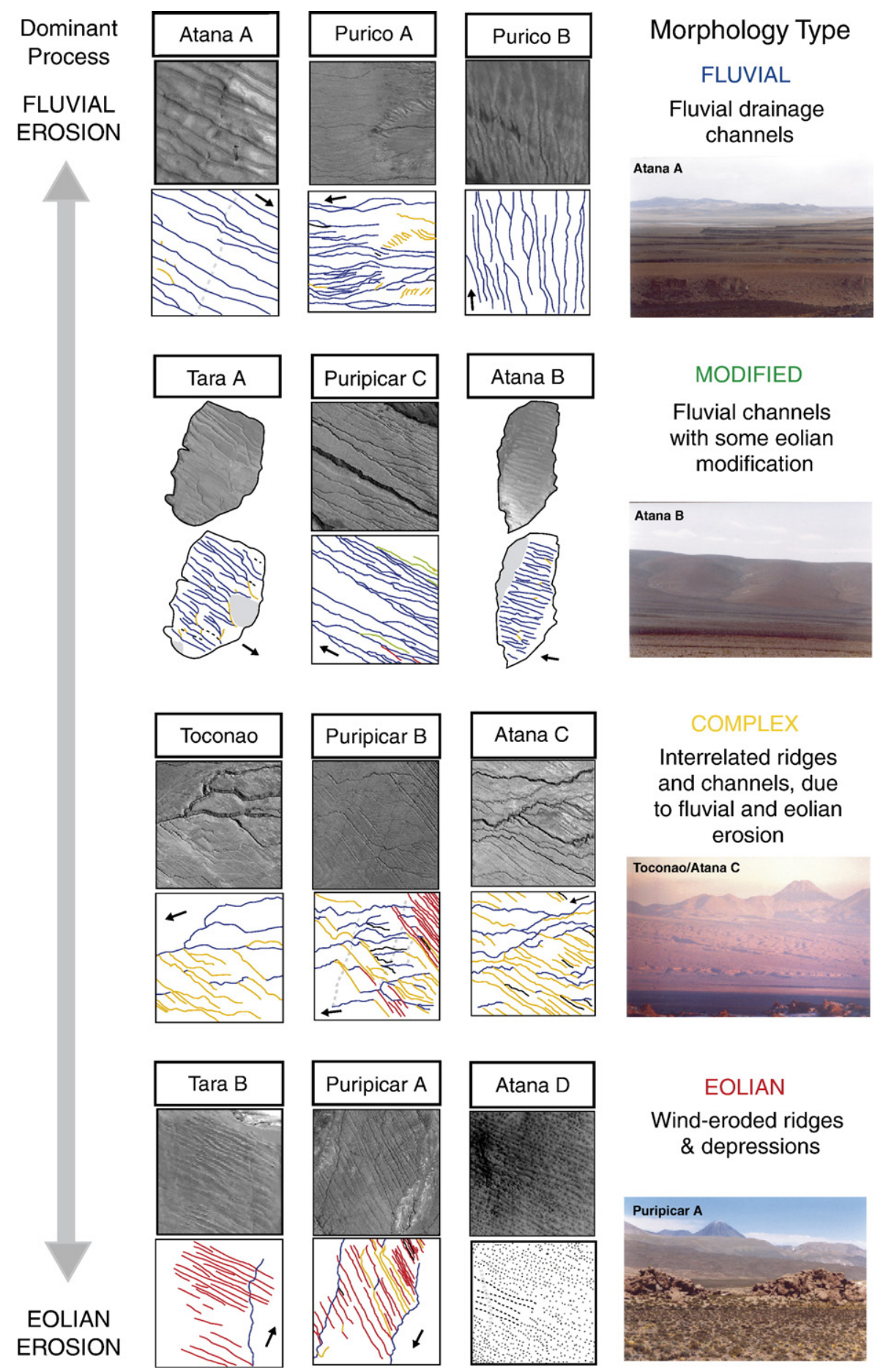

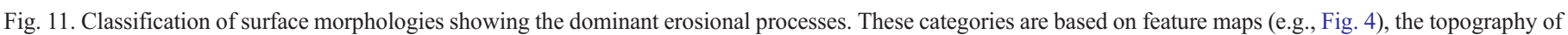
each site, and the quantitative analysis of geomorphologic characteristics (Fig. 8). Photos of example sites from each category are shown (right). 
one channel into another has led to abandonment of previous incipient pathways (Figs. 3 and 9a). Eroded tafoni textures on loose ignimbrite boulders (Fig. 9b) and a pervasive covering of desert paving (Fig. 5c), indicate that significant eolian erosion has occurred. The site is a remnant of a larger ignimbrite plateau, so is now raised relative to the surrounding topography (Fig. 6c).

Similarly at Puripicar C there is evidence of features shaped by fluvial and eolian erosion. Field observations of plunge pools within wider channels suggest fast flowing water played a role in shaping the landscape (Fig. 9c,d). However, the DEM has shown the area to the SW contains topographic ridges (Fig. 6d), which suggests sculpting by wind.

The effects of eolian modification are less obvious at Atana B. The channels are highly linear and separated by low, well-rounded ridges (Fig. 6b). Landforms at Atana B appear to be a less developed version of those at Tara A. This could reflect the younger age of the Atana ignimbrite and the fact that it was emplaced shortly before the time when it is now thought the climate in the Atacama Desert became predominantly hyper-arid (Gaupp et al., 1999; Hartley \& Guillermo Chong, 2002). Thus, there might have been limited opportunity for fluvial erosion to occur, and this lack of incipient valley formation would have reduced the effectiveness of eolian erosion.

The most complicated patterns of features are seen at Toconao, Puripicar B and Atana C sites. The plotted values for these on Fig. 9c show moderate values of $\Delta$, and high $S$ values (relative to other sites). The feature maps show there is a complex mixture of along-slope and cross-slope channels, together with cross-slope ridges at Puripicar B. The along-slope channels form an interconnected drainage network, but superimposed on this are the linear cross-slope channels and ridges, which are all aligned roughly NW-SE (Fig. 6e,f). They frequently originate on the south bank of larger channels (Fig. 9e), are sometimes connected to other channels at the other end, and in some cases have been adopted as a fluvial pathway. Although this could imply they are of a fluvial origin, their linear nature and alignment in a coherent, cross-slope direction suggests at least initial formation by eolian erosion along a dominant wind direction.

Particularly difficult to define is the landscape at Puripicar $\mathrm{B}$, which appears to transform into a different morphology in the NE section of the site. The feature map shows a mixture of fluvial, complex and eolian features, whilst the value of $S_{\text {mean }}$ vs. $\Delta_{\text {mean }}$ plots on the boundary between complex and eolian-dominated (Fig. 8c). The higher value of $S_{\text {mean }}$ allows for categorization of this landscape as complex, but were the sample site moved a few kilometers to the NW, the landscape would probably be found to be eolian-dominated. Interestingly, this would place further into the area where much of Greene's (1995) Puripicar Ignimbrite yardang study was undertaken.

Based on Fig. 8c, Puripicar A could also potentially be considered complex, however, the low value of $S_{\text {mean }}$ and the domination of linear ridges (Fig. $6 \mathrm{~g}$ ) in the feature map suggest the landscape was predominantly shaped by eolian-erosion.
Low $S_{\text {mean }}$ and high $\Delta$ values identify features at Tara B that are clearly dominantly wind-eroded. A fluvial drainage channel is apparent but this feature follows the slope and winds in between the gently undulating terrain. The rest of the measured features are unconnected, linear ridges that are exposed atop the undulations and are aligned almost perpendicular to the regional slope (Figs. 5b and 6h).

A totally different geomorphology to the landscapes described for the other 11 sites is found at Atana D (Fig. 10). The Landsat images show hundreds of distinctive round
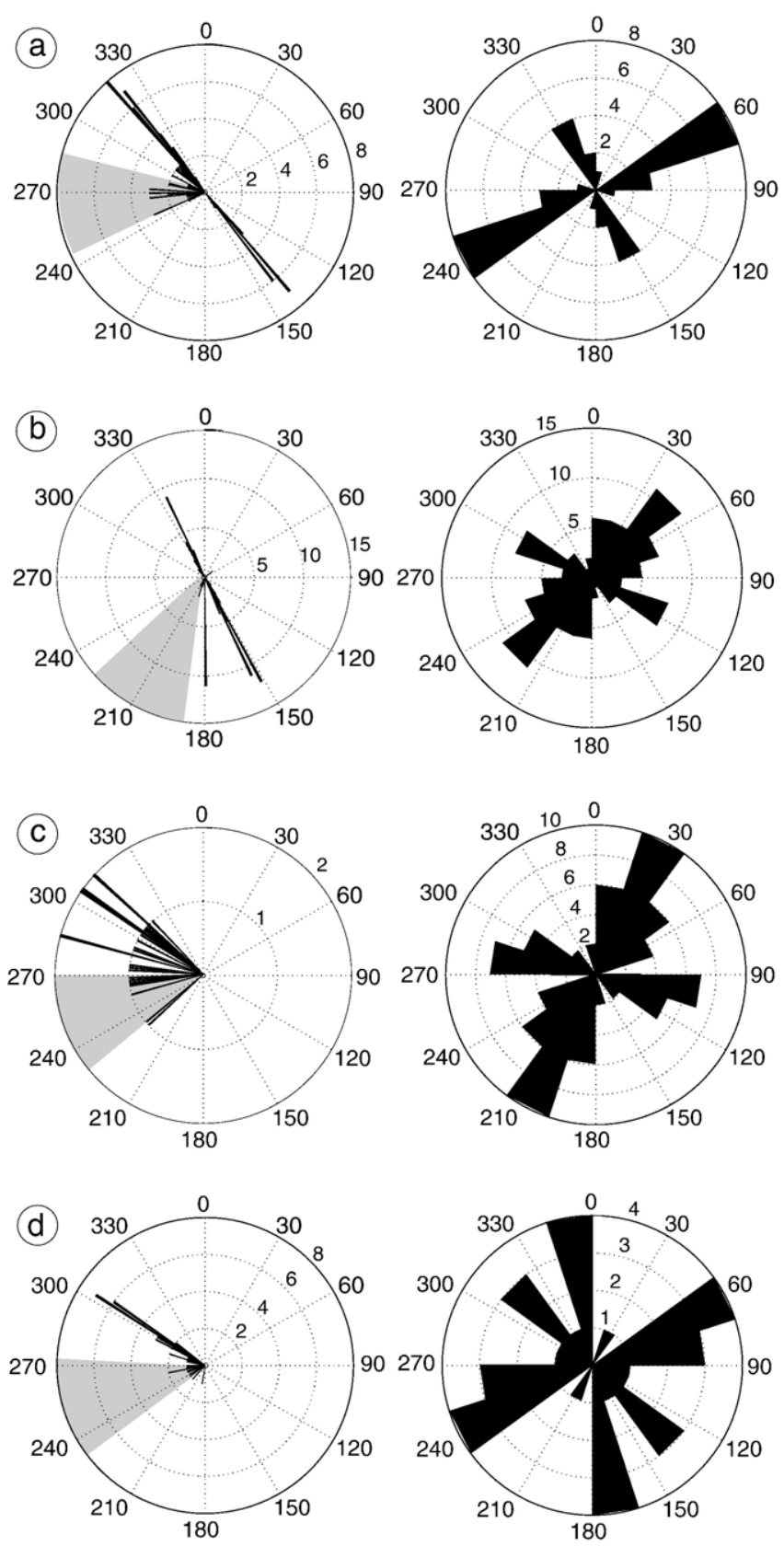

Fig. 12. Comparison of feature orientation (left) with the orientations of cooling joints (right) at four sites measured in the field: (a) Puripicar B, (b) Puripicar A, (c) Toconao, and (d) Atana C. Shaded areas indicate those features that are defined as along-slope; unshaded as cross-slope. 
features arranged in NW-SE trending linear alignments. When the features were observed in the field they were found to be subtle depressions in the ignimbrite surface. Also know as blowouts in the terminology of desert landforms, these basins result from the concentration of deflation processes (Peel, 1960; Said, 1962). It is not clear why deflation and the formation of blowouts should be so prevalent in this area, but they do appear to form as aligned chains (Fig. 10a), suggesting it is the first stage in eolian erosion of the landscape in the style suggested by Embabi (1999; Fig. 5a).

Categorization of the landscape morphologies at the 12 study sites was made based on the qualitative and quantitative analyses described. Each site was placed into the category that best describes its landscape as highlighted by the mapped fea- tures, the topography and geomorphic measurements (Table 1). These categorized are visualized as a spectrum of the relative dominance of fluvial and eolian erosion processes (Fig. 11). Using the categories for each site, and an assessment was made of feature frequency vs. ignimbrite age, where:

\section{Feature Frequency}

$$
=\text { Study Area }\left(\mathrm{km}^{2}\right) / \text { Number of Features }
$$

Fig. 8d shows the comparison and suggests that fluvial features dominate for younger landscapes and eolian features are dominant for older terrain. However, it is impossible to assess any transition between these two extreme cases as ignimbrite ages are similar for most of the sites.

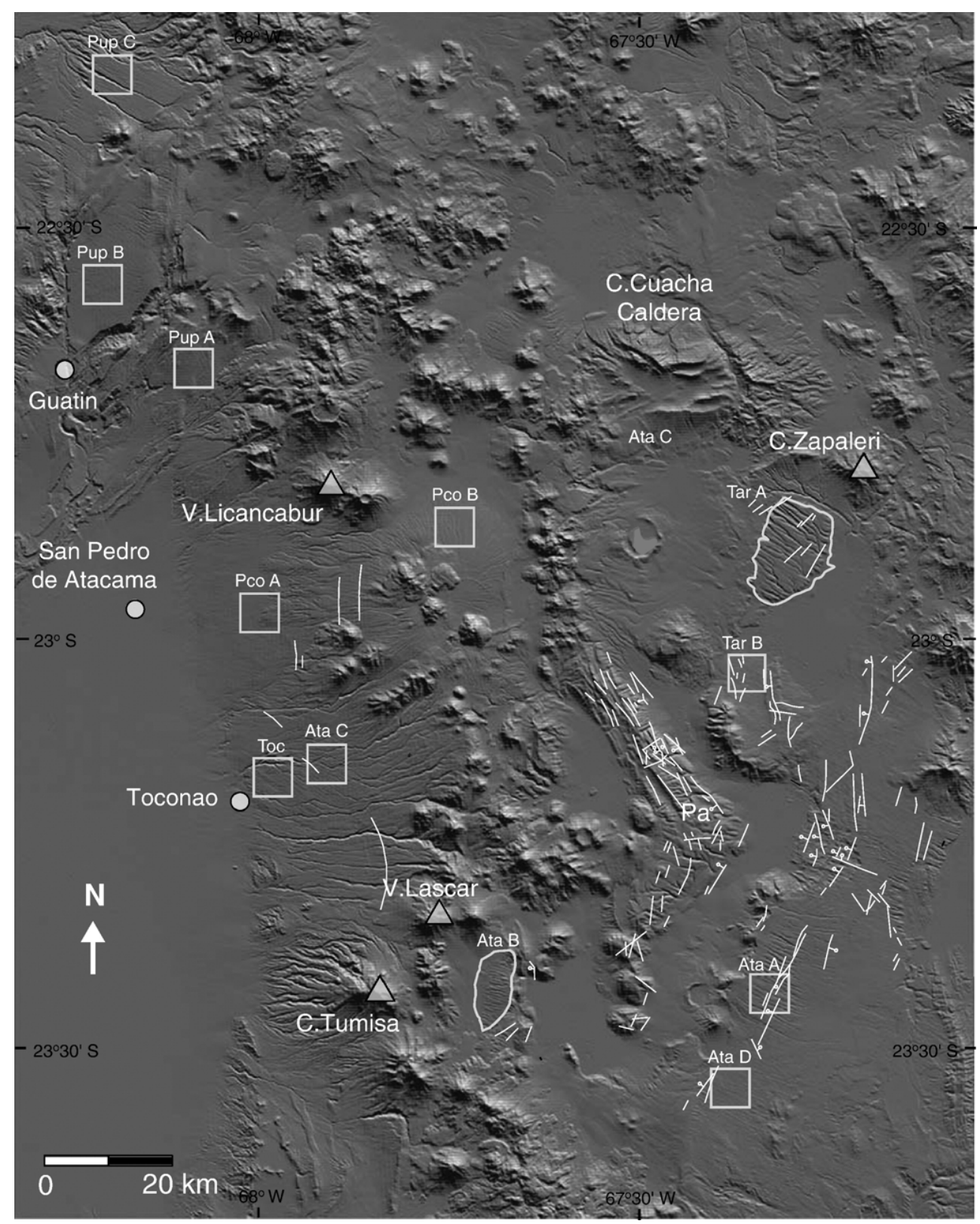

Fig. 13. Regional faults (based on Ramírez \& Gardeweg, 1982; Gardeweg \& Ramírez, 1987) shown on shaded relief map derived from SRTM-DEM. Illumination is from NE. Abbreviations used the same as Fig. 6. 


\section{Influences on erosion processes}

Another goal of this study was to define the origins of the NW-SE trending linear surface features that are prevalent in the surface morphology at several of the study sites, and throughout this ignimbrite-dominated landscape region. The coherence in the alignment of many of these features, across multiple sites, must imply something about either the conditions of formation and/or properties of the ignimbrites or their surfaces.

Vegetation patterns cannot be considered a control on the erosion pattern, as the hyper-arid climate has created a very barren landscape. Similarly, welding and vapor-phase alteration of ignimbrites tends to be pervasive across a deposit, and also do not appear to provide regional influence on erosion. However, these hardening mechanisms do involve the formation of cooling joints throughout an ignimbrite (Fig. 9f), providing potential planes of weakness on a smaller scale than regional faulting. It is suggested that the joints could help influence the pervasive NW-SE alignment of wind-derived features.

Data from the Atana, Toconao and Puripicar Ignimbrites show that cooling joints have major and minor axes of distribution (Fig. 12). The major axes trend roughly NE-SW and the minor axes are perpendicular to this, trending approximately NW-SE. The predominant tectonic grain in the region also parallels the dominant $\mathrm{NW}-\mathrm{SE}$ trend of features (Allmendinger et al., 1997), and this has possibly influenced the formation joint direction, as suggested by Gxuest (1969). However, no implicit correlation can be found between studies of regional faulting and the location of surface features (Fig. 13). It appears that the minor axes of joint planes have encouraged development of wind-derived features but are not the main controlling factor for the dominant NW-SE feature alignment. This factor is the direction of the wind itself.

Studies of the current climate show that wind in the region is dominantly from the NW (Das et al., 1998). So the question is how long would these conditions have had to exist to form the fields of coherently aligned linear features that have been identified in this study? We know from other ignimbrite studies that unless highly consolidated, freshly deposited sheets can be rapidly removed in wetter environments. For example, after 5 years, $\sim 50 \%$ of the 1991 Mt. Pinatubo ignimbrite sheet had been remobilized and transported down-slope (Daag \& van Westen, 1996; Montgomery et al., 1999). Even if an ignimbrite does become welded and vapor-phase altered, it has been inferred that initial erosion of the ignimbrite can still be rapid (Bailey, 2005). Eolian-erosion processes occur far slower. Thus the incipient patterns of fluvial channels, including the sites where regional slope and features are aligned NW-SE, could have been emplaced shortly after the ignimbrites' deposition, but wind-modification of the channels has taken up to several millennia.

The fact that the NW-SE aligned features are not present on the Purico Ignimbrite surface implies that either they were formed by a mechanism only present before the Purico's emplacement $(1.35 \pm 0.15 \mathrm{Ma})$, or that the formation process requires a period of time longer than this age. Alternatively, the
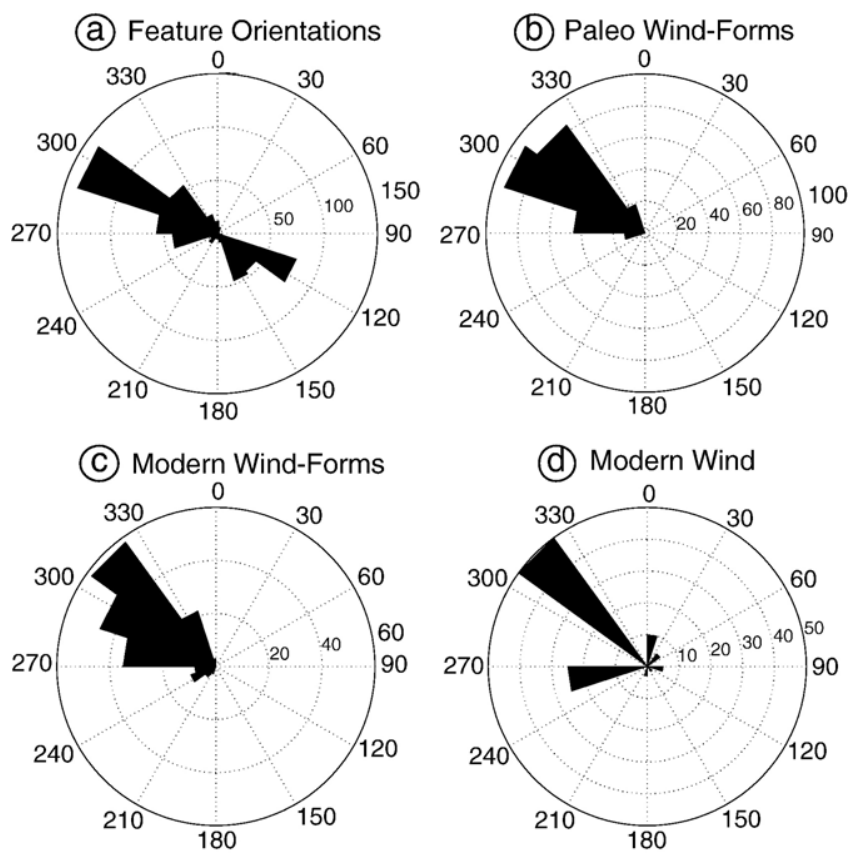

Fig. 14. Evidence for modern and paleo wind directions around La Pacana Caldera. (a) Cumulative orientations of studied surface features. (b) Modern wind directions based erosional structures in Puripicar Ignimbrite (Greene, 1995). (c) Modern wind directions based erosional structures in Puripicar Ignimbrite (Greene, 1995). (d) Survey of current atmospheric circulation conditions (Das et al., 1998).

Purico Ignimbrite could consist of material unsuitable for the development of NW-SE aligned features but there is no obvious reason for this to be so based on field observation. Moreover, this last point seems unlikely as NW-SE aligned channels and ridges features are found in ignimbrites with different degrees of induration and welding, and different proportions of coarse and fine particles. In this regard the Purico Ignimbrite is no more unique than any of the other deposits. The lack of wind-related features is more likely a consequence of the Purico Ignimbrite's younger age (Fig. 8d).

The feature orientations measured in this study, and Greene's (1995) studies of the wind-related geomorphology in the Puripicar Ignimbrite, suggest that strong uni-directional winds from the northwest have been constant over a long period of time. Greene (1995) speculated that the region's atmospheric circulation system has been stable since the Pleistocene or late Pliocene, i.e., $>2 \mathrm{Ma}$, although the evidence for this stability is not conclusive. It does appear, therefore, that the linear, NW-SE alignments seen around La Pacana can be attributed primarily to the dominant NW winds (Fig. 14), which have likely blown from that direction for a prolonged period of time.

\section{Conclusions}

This study is the first to use SRTM data to describe the morphology of a large ignimbrite landscape. The combination of an SRTM-derived DEM with Landsat TM and ETM+ images allows measurement of landscape features on the order of $10 \mathrm{~s}-$ $100 \mathrm{~s} \mathrm{~m}$, across $100 \mathrm{~s} \mathrm{~km}^{2}$ of terrain. These features are too large 
and widespread to study solely through ground surveys. Field observations were made in order to aid interpretation. The most prevalent features are fluvial-derived channels but the most distinctive are linear, wind-derived ridges. These have been termed yardangs after similar features identified throughout the literature concerning arid landscape geomorphology, and this is one of very few studies to identify yardangs in volcanic terrains (Greene, 1995; Inbar \& Rossi, 2001).

One important intention of this work was to determine whether the general character of the landscape could be categorized based on features that were visible within the spatial and vertical resolution of the SRTM-derived DEM and Landsat images, using a minimum of field-based observations. In this regard, the SRTM-derived DEM was useful as they generally allowed the topographic type (ridge or channel) of a feature to be identified. However, the vertical resolution of the DEM $(\sim 12-16 \mathrm{~m})$ is insufficient to make measurements of individual features' height or depth. We are therefore unable to comment upon the relative degree of erosion in different areas of ignimbrite of the same age. Visual identification of features was often found to be easier in the (higher spatial resolution) Landsat images, which suggests that a higher spatial resolution digital elevation model, collected either by NASA's TOPSAR instrument (Zebker et al., 1992) or an airborne lidar instrument would further assist in the characterization of the ignimbrite surfaces investigated here.

Four types of features were identified; channels aligned along-slope (fluvial), channels aligned cross-slope (complex), ridges aligned cross-slope (eolian) and ridges aligned alongslope (modified). These combine to create a range of landscape morphologies, several of which are a complex inter-relationship of wind- and fluvial-eroded features. The along-slope channels were identified on images as curvilinear features that may be $>10 \mathrm{~km}$ long, and form sub-parallel, bifurcating drainage patterns (Howard, 1967). Evidence such as tafoni and desert pavement erosional textures suggests that some fluvial channels have had their morphology significantly modified by wind erosion. This is most prevalent at sites where the regional slope and the fluvial channels are aligned NW-SE, e.g., Tara A and Atana B. The channels that lie cross-slope were often more linear features. They are mostly aligned along the NW-SE trend and generally form off of the south bank of larger fluvial channels, e.g., Toconao, Puripicar B and Atana C. Cooling joints might have aided their formation but the alignment and morphology suggests the prevalent wind direction was the primary influence on the style of erosion. In some instances drainage pathways appear to have adopted these channels as a diversion from their original route.

For some of the landscapes studied, wind erosion appears to have been the dominant process, e.g. the disconnected patterns of yardangs seen at sites Puripicar A and Tara B. There is a high coherency in the orientation of these features, with all of them lying on a roughly NW-SE trend. Wind erosion has also created alignments of depressions identified as deflation pits, as seen at site Atana D.

For many of the sites studied the initial patterns of erosion were most likely due to fluvial erosion. Wind erosion then occurred over a longer period of time, either imprinting a second pattern of features (e.g, Toconao Ignimbrite), modifying the existing pattern of channels (e.g., Tara A) or eroded a new morphology totally separate of any existing fluvial drainages (e.g., Tara B). In some cases this pattern was then further modified by further fluvial activity (e.g., Puripicar A). The coherent NW-SE alignment of wind-derived features suggests that uni-directional winds (from the northwest) have been dominant for a long period of time. Speculation on the timescales of processes suggest that the incipient fluvial pattern was imprinted very soon after ignimbrite deposition, but the formation of wind-eroded channels and yardangs took at least 1-2 Ma.

\section{Acknowledgements}

This work forms the basis of one aspect of the Ph.D. research of John Bailey, which was supported by NASA Earth System Science Fellowship Grant NGT5-50319. The authors would like to thank Kirti Sharma (Open University, U.K.) and Joaquin Cortes (Univ. of Buffalo) for invaluable assistance in the field, and the Anofagasta branch of Servicio Nacional de Geología y Mineria (Sernageomin) for providing logistical support. L.K. Wooller's and K. Sharma's fieldwork was supported by the Peter Francis Travel Bursary (Open University, U.K.). We also thank Shan de Silva and the manuscript reviewers for helpful and insightful comments.

\section{References}

Allmendinger, R. W., Isacks, B. L., Jordan, T. E., \& Kay, S. M. (1997). The evolution of the Altiplano-Puna plateau of the Central Andes. Annual Review of Earth Sciences, 25, 139-174.

Alpers, C., \& Brimhall, G. (1988). Middle Miocene climatic change in the Atacama Desert, northern Chile: Evidence from supergene mineralization at La Escondida. Geological Society of America Bulletin, 100, 1640-1656.

Bailey J. E. (2005). Evolution of dynamic volcanic landscapes, PhD Dissertation, University of Hawaii, $250 \mathrm{pp}$.

Baker, M. C. W., \& Francis, P. W. (1978). Upper Cenozoic ignimbrite centers in the Central Andes. Journal of Volcanology and Geothermal Research, 11, 293-315.

Brookes, I. A. (2001). Aeolian erosional lineations in the Libyan Desert, Dakhla Region, Egypt. Geomorphology, 39, 189-209.

Clark, A. H., Meyer, E. S., Mortimer, C., Sillitoe, R. H., Cooke, R. U., \& Snelling, N. J. (1967). Implications of the isotope ages of ignimbrite flows, southern Atacama Desert, Chile. Nature, 215, 723-724.

Clark, A. H., Tosdal, R. M., Farrar, E., \& Plazolles, V. A. (1990). Geomorphologic environment and age of supergene enrichment of the Cuajone, Quellaveco, and Toquepala porphyry copper deposits, southern Peru. Economic Geology, 85, 1604-1628.

Daag, A., \& van Westen, C. J. (1996). Cartographic modeling of erosion in pyroclastic flow deposits of Mount Pinatubo, Philippines. ITC Journal, 2 , 110-124.

Das, D. K., Jarratt, D., McDonald, D., \& Heberlein, D. (1998). Environmental baseline data collection at Diablillos property, Salta, Argentina. Rescan Envionmental Services and Barrick Exploraciones Argentina S.A. 15 pp.

de Silva, S. L. (1987). Large volume explosive silicic volcanism in the Central Andes of N.Chile. PhD thesis, Open University, U.K., 409 pp.

de Silva, S. L. (1989). Altiplano-Puna volcanic complex of the Central Andes. Geology, 17, 1102-1106.

de Silva, S. L. (1989). Geochronology and stratigraphy of the ignimbrites from the $21^{\circ} 30^{\prime} \mathrm{S}$ to $23^{\circ} 30^{\prime} \mathrm{S}$ portion of the Central Andes of northern Chile. Journal of Volcanology and Geothermal Research, 37, 93-131. 
de Silva, S. L., \& Francis, P. W. (1989). Correlation of large ignimbrites; two case studies from the Central Andes of northern Chile. Journal of Volcanology and Geothermal Research, 37, 133-149.

Embabi, N. S. (1999). Playas of the Western Desert, Egypt. Annales Academiae Scientiarum Fennicae. Geologica - Geographica, 160, 5-47.

Farr, T. G., \& Kobrck, M. (2000). Shuttle Radar Topography Mission provides wealth of data. American Geophysical Union Eos, 81, 583-585.

Francis, P. W., Sparks, R. S. J., Hawkesworth, C. J., Thorpe, R. S., Pyle, D. M., Tait, S. R., et al. (1989). Petrology and geochemistry of volcanic rocks of the Cerro Galán Caldera, northwest Argentina. Geological Magazine, 126, 515-547.

Galli-Oliver, C. (1967). Pediplain in northern Chile and the Andean Uplift. Science, 158, 653-655.

Gardeweg, M., \& Ramírez, C. F. (1985). Carta geológica de Chile No.66: Hoja Rio Zapaler, Regíon de Antofagasta.: Servicio Nacional de Geología y Minería $89 \mathrm{pp}$.

Gardeweg, M., \& Ramírez, C. F. (1987). La Pacana caldera and the Atana ignimbrite - A major ash-flow and resurgent caldera complex in the Andes of northern Chile. Bulletin Volcanologique, 49, 547-566.

Gaupp, R., Kött, A., \& Wörner, G. (1999). Palaeoclimatic implications of MioPliocene sedimentation in the high-latitude intra-arc Lauca basin of northern Chile. Palaeogeography, Palaeoclimatology, Palaeoecology, 151, 79-100.

Greene, L. L. (1995). Eolian landforms in the central Andes: Implications for the long-term stability of atmospheric circulation. M.S. thesis, Cornell University, Ithaca, $62 \mathrm{pp}$.

Guest, J. E. (1969). Upper Tertiary ignimbrites in the Andean Cordillera of part of the Antofagasta province of northern Chile. Geological Society of America Bulletin, 80, 337-362.

Hartley, A. J., \& Guillermo Chong, G. (2002). Late Pliocene age for the Atacama Desert: Implications for the desertification of western South America. Geology, 30, 43-46.

Houston, J. (2001). La precipitacion torrencial del ano 2000 en Quebrada Chacarilla y el calculo de recarga al acuifero Pampa Tamarugal, norte de Chile. Revista GeoloAgica de Chile, 28, 166-173.

Houston, J. (2002). Groundwater recharge through an alluvial fan in the Atacama Desert, northern Chile: Mechanisms, magnitudes and causes. Hydrological Processes, 16, 3019-3035.

Howard, A. D. (1967). Drainage analysis in geologic interpretation: A summation. American Association of Petroleum Geologists Bulletin, 51, 2246-2259.

Inbar, M., \& Rossi, C. (2001). Holocene yardangs in volcanic terrains in the Southern Andes, Argentina. Earth Surface Processes and Landforms, 26, 657-666.

Kull, C., \& Grosjean, M. (1998). Albedo changes, Milankovitch forcing, and late Quaternary climate changes in the central Andes. Climate Dynamics, $14,871-881$.

Lahsen, A. (1982). Upper Cenozoic volcanism and tectonism in the Andes of northern Chile. Earth-Science Reviews, 18, 285-302.

Latorre, C., Betancourt, J. L., Rylander, K. A., Quade, J., \& Matthei, O. (2003). A vegetation history from the arid prepuna of northern Chile $\left(22-23^{\circ} \mathrm{S}\right)$ over the last 13,500 years. Palaeogeography, Palaeoclimatology, Palaeoecology, 194, 223-246.

Lindsay, J. M. (1999). Stratigraphy, age relations and magmatic evolution of large-volume felsic ignimbrites of the La Pacana Caldera, Central Andes,
Chile. Scientific technical report STR99/16 Potsdam: Geoforschungszentrum Potsdam 141 pp.

Lindsay, J. M., de Silva, S., Trumbull, R., Emmermann, R., \& Wemmer, K. (2001). La Pacana caldera, N.Chile: A re-evaluation of the stratigraphy and volcanology of one the world's largest resurgent calderas. Journal of Volcanology and Geothermal Research, 106, 145-173.

Lindsay, J. M., Schmitt, A. K., Trumbull, R. B., de Silva, S. L., Siebel, W., \& Emmermann, R. (2001). Magmatic evolution of the La Pacana Caldera System, Central Andes, Chile: Compositional variation of two cogenetic, large-volume felsic ignimbrites. Journal of Petrology, 42, 459-486.

Marinoviç, N., \& Lahsen, A. (1984). Carta geológica de Chile No.58: Hoja Calama, Region de Antofagasta.: ServicioNacional de Geología y Minería $140 \mathrm{pp}$.

Mason, B. G., Pyle, D. M., \& Oppenheimer, C. (2004). The size and frequency of the largest explosive eruptions on Earth. Bulletin of Volcanology, 66, 735-749.

Montgomery, D. R., Panfil, M. S., \& Hayes, S. K. (1999). Channel-bed mobility response to extreme sediment loading at Mount Pinatubo. Geology, 27, 271-274.

Mortimer, C., Farrar, E., \& Saric, N. (1974). K-Ar ages from Tertiary lavas of the northernmost Chilean Andes. Geologische Rundschau, 63, 484-493.

Mortimer, C., \& Saric, N. (1975). Cenozoic studies in northernmost Chile. Geologische Rundschau, 64, 395-420.

Peel, R. A. (1960). Some aspects of desert geomorphology. Geography, 45, 241-262.

Pichler, H., \& Zeil, V. W. (1972). The Cenozoic rhyolite-andesite association of Chilean Andes. Bulletin Volcanologique, 35, 424-452.

Rabus, B., Eineder, M., Roth, A., \& Bamler, R. (2003). The shuttle radar topography mission - A new class of digital elevation models acquired by spaceborne radar. Photogrammetry and Remote Sensing, 57, 241-262.

Ramírez, C. F., \& Gardeweg, M. (1982). Carta geológica de Chile No.54: Hoja Toconao, Regíon de Antofagasta: Servicio Nacional de Geología y Minería $122 \mathrm{pp}$.

Rech, J. A., Quade, J., \& Betancourt, J. L. (2002). Late Quaternary paleohydrology of the central Atacama Desert (lat 228-248S), Chile. Geological Society of America Bulletin, 114, 334-348.

Rutland, R. W. R., Guest, J. E., \& Grasty, R. L. (1965). Isotopic ages and Andean uplift. Nature, 208, 677-678.

Said, R. (1962). The geology of Egypt.Amsterdam: Elsevier 377 pp.

Sillitoe, R., \& McKee, H. (1996). Age of supergene oxidation and enrichment in the Chilean porphyry copper province. Economic Geology, 91, 164-179.

Sparks, R. S. J., Self, S., \& Walker, G. P. L. (1973). Products of ignimbrite eruptions. Geology, 1, 115-118.

Thompson, M. V., Palma, B., Knowles, J. T., \& Holbrook, N. M. (2003). Multiannual climate in Parque Naciional Pan de Azúcar, Atacama Desert, Chile. Revista Chilena de Historia Natural, 76, 235-254.

Whitney, M. I. (1978). The role of vorticity in developing lineation by wind erosion. Geological Society of America Bulletin, 89, 1-18.

Zebker, H. A., Madsen, S. N., Martin, J., Wheeler, K. B., Miller, T., \& Lou Y, Y. (1992). The TOPSAR interferometric radar topographic mapping instrument. IEEE Transactions on Geoscience and Remote Sensing, 30, 933-940. 